\title{
PATTERNED QUAKING MIRE AT HANDSPIKE POINT, MACQUARIE ISLAND
}

\author{
by J. Rich
}

(with two tables, eight text-figures, two plates)

RICH,]., 1996 (30:vi): Pamrned quaking mire at Handspike Point, Macquarie Island. Pap. Proc. R. Soc. Tasm. 130( 1 ): 49-65. https://doi.org/10.26749/rstpp.130.1.49 ISSN 0080-4703. School of Biological and Environmental Sciences, Murdoch University, Murdoch, Western Australia 6150.

Raised mires occur on an emerging marine terrace of Holocene age at Handspike Point, Macquarie Island, and slope seawards. Porrions of these mires are characterised by numerous, anastomosing to parallel, low pear ridges, separated by waterlogged troughs. The resulting patterns are accentuated by the distinctive rosette plant Pleurophyllum hookeri, which grows only on the ridges. Sampling suggests that ridge and trough patterns persist to at least $1.5 \mathrm{~m}$ depth. Pleurophyllum colonisation appears to be a function of the difference in trough:ridge peat bulk density. As this density ratio approaches 0.8 , waterlogging decreases and Pleurophyllum vigour is enhanced.

Patterns are oriented at various angles to the present surface slopes, but roughly parallel to the plateau margin and normal to the regional slope of the marine terrace. The divergence between patrern and local contour orientation results from non-uniform accretion. Patterns at angles to the contours appear to provide benefits which include enhanced water-level stability.

The Handspike mires exhibit many characteristics of patterned and non-patterned peatlands ubiquitous throughout the Northern Hemisphere, with particular similarities to eccentric domed mires of the Baltic region. Vertical accretion is estimated to average $1 \mathrm{~mm} \mathrm{yr}^{-1}$; lateral accretion appears to be in equilibrium with the emerging marine terrace.

Key Words: Patterned mire, raised mire, peat, Macquarie Island, subantarctic.

\section{INTRODUCTION}

Macquarie Island $\left(54^{\circ} 37^{\prime} \mathrm{S}, 158^{\circ} 53^{\prime} \mathrm{E}\right)$ is seismically active and is rising at rates variously estimated to be between 1.7 and $4.5 \mathrm{~mm} \mathrm{yr}^{-1}$ (Colhoun \& Goede 1973, Adamson et al. 1988). Prior to sea-level stabilisation 6000 to 7000 years ago, sea level rose faster than the island, resulting in vigorous marine erosion and coastal cliff retrear (Adamson et al. 1988). Continuous uplift since that time is reflected in a raised marine terrace which is now the dominant landform along the northern two-thirds of the west coast (Blake in Mawson 1943, Colhoun \& Goede 1973, Selkirk et al. $1990 \mathrm{~b})$. This terrace is up to $1 \mathrm{~km}$ wide and rises from the shore at slopes of $2^{\circ}$ ro $4^{\circ}$ (Adamson et al. 1988). Steep slopes or cliffs form the inland edge of the terrace and define the limit of former marine erosion. The climate is dominated by persistent, strong west co northwesterly winds, frequent low cloud and fog, and a narrow range of temperature.

Water-saturated quaking mires, known locally as fearherbed, occur in a number of areas along the raised marine terrace. At Handspike Point, quaking blanket mire is the dominant landform (fig. 1). Portions of the Handspike mires display distinctive linear patterns which have not been described from elsewhere on Macquarie Island. These consist of slightly elevared, relatively drier pear ridges, separated by wetter troughs. The resulting striped pattern is furcher accentuated by the distinctive, large-leafed, greygreen roserte plant Pleurophyllum hookeri Buchan, which grows on many of the ridges. The paterns were first described by Hamilcon (1926), biologist wich Mawson's 1911-1914 Australasian Antarctic Expedicion (AAE) party. Hamilton considered that the stripes were parallel to the prevailing wind direction and that Pleurophyllum seeds were distributed down wind, seedlings establishing in the lee shelter provided by the parent plants. This theory was reiterared by Taylor (1955), who also considered the lines to be roughly parallel to the prevailing winds. Selkirk $e t$ al. (1990a) were the first to point out that the stripes are not parallel to the prevailing wind. They noted that their origin remained unexplained.

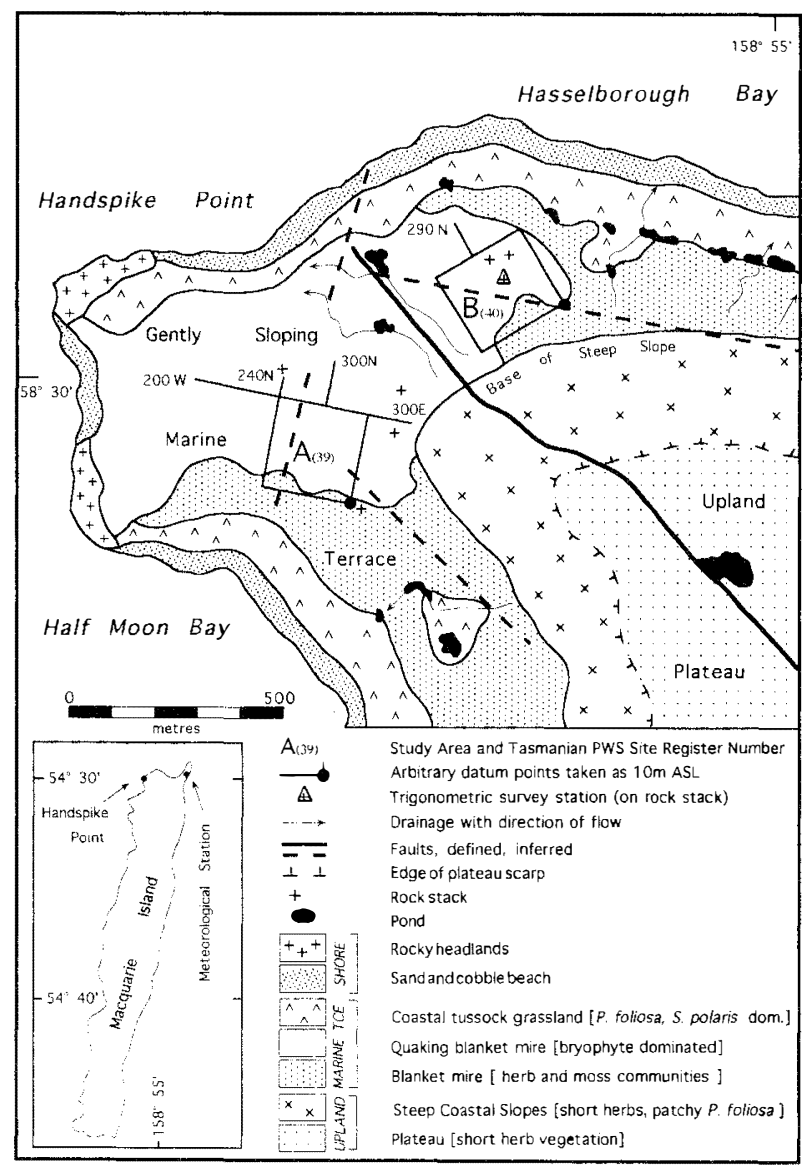

FIG. I - Location map showing physiography, vegetation communities and study areas. 
Patterned peatlands are widespread throughout the temperate and subpolar regions of the Northern Hemisphere. They include such land forms as string bogs and fens (Sjors 1961, Washburn 1979, Glaser \& Janssens 1986) and various forms of patterned mires (Moore \& Bellamy 1974, Glaser et al. 1981). Patterned peatlands include domed or raised mires and bogs in which convex masses of peat grow above the original water table (Moore \& Bellamy 1974). In all of these features, peat strings or ridges of relatively higher relief are separated by depressions (troughs or flarks) which are commonly water-filled. Numerous hypotheses have been advanced to explain specific examples (Thompson 1983, Foster et al. 1983, Kirkpatrick \& Gibson 1984, Whinam 1985). However, it is likely that superficially similar landforms develop on different sites through a number of processes, each with varying biotic, periglacial and gravitational components (Moore \& Bellamy 1974). Wetlands may be either zones of ground water recharge or discharge (Siegel 1988). The distribution of ombrotrophic bogs and minerotrophic fens may be largely controlled by local ground water flow systems (Siegel 1983). Climate, particularly precipitation and presence or absence of an annual period of freezing, also appears important, and the classification and distribution of many forms of patterned peatland have been tied to climatic factors (Drury 1956, Thom 1972, Brown \& Péwé 1973, Moore \& Bellamy 1974, Dewez et al. 1984).

During the winter of 1990, two study sites which included areas of Pleurophyllum stripes were established on the Handspike mires (fig. 1). These are included on the Tasmanian Parks and Wildlife Service (PWS) Macquarie Island Study Site Register as sites 39 and 40. It became evident from an early stage that Hamilton's "wind rows" and Taylor's "wind line complexes" were inappropriate names because they carried firm but as yet unjustified genetic connotations. The term "patterned mire" has been adopted to describe these features.

Despite speculation about the Handspike mires since at least 1911, no systematic physical surveys or descriptions had been made prior to this study. Probing showed that the mires are very deep (up to $5.9 \mathrm{~m}$ ) and suggested that the surface patterns persisted at depth. The present paper presents the first detailed description of the surface and subsurface characteristics of the Macquarie Island patterned mires and provides evidence that the present surface patterns were formed at an early stage of mire development and have persisted during vertical accretion. In places, the patterns may provide an additional mechanism of waterlevel regulation within the mire.

\section{PHYSIOGRAPHIC SETTING OF THE STUDY AREA}

The principal physiographic features and vegetation communities are summarised in figure 1 . Coastal tussock grasslands dominated by Poa foliosa (Hook. f.) Hook. f. and Stilbocarpa polaris (Homb. et Jacq.) Gray (Macquarie Island cabbage) fringe the beaches along Hasselborough Bay and Half Moon Bay. A rise in elevation of several metres in many places defines the landward transition to blanket mires. The mires have convex surfaces which vary from smooth to hummocky and consist of peat, supporting mixed and highly variable herb and moss communities. Taylor (1955) and Selkirk et al. (1990a) provided detailed descriptions.
Within the blanket mire are extensive areas of bryophytedominated quaking mire, portions of which are patterned. Transition from blanket to quaking mire varies from gradational to sharp. At Handspike Point, the quaking mires extend west to the beach, where they are punctuated by numerous rock stacks and low outcrops. A transition zone approximately $100 \mathrm{~m}$ wide, parallel to the beach, is characterised by numerous staircase ponds dammed by the cushion plant Azorella macquariensis Orchard.

Steep $\left(25^{\circ}-35^{\circ}\right)$ coastal slopes rise from the inland edge of the raised marine terrace to the island plateau. The slopes support short-herb communities mixed with patchy Poa foliosa and Stilbocarpa polaris. Short-herbfield vegetation predominates on the plateau.

Study Areas A and B collectively comprise 8.4 ha and include the largest areas of patterned mire. The Handspike Point patterned mires (estimated total extent $12 \mathrm{ha}$ ) represent the only reported occurrence of this landform on the island.

\section{MATERIALS AND METHODS}

Survey grids defined by wooden pegs (lines $20 \mathrm{~m}$ apart, pegged every $10 \mathrm{~m})$ were placed over Area A $(200 \times 200 \mathrm{~m})$ and Area $B(200 \times 220 \mathrm{~m})$. All grid points in both areas were oprically levelled, to an accuracy of $\pm 1 \mathrm{~cm}$, each with an arbitrary datum (fig. 1). No attempt was made to tie the two surveyed areas together, nor were the datum points tied to sea level, or the trig. station. Detailed maps of surface topography were prepared for each area. Mire thickness was measured by probing along selected grid lines at 10 and $20 \mathrm{~m}$ intervals using a $6 \mathrm{~m}$ length of $13 \mathrm{~mm}$ copper pipe. These data were tied to the surface levels, and detailed sections of the subsurface topography were constructed. Surface and subsurface slopes were calculated by linear regression. Rate and direction of surface water flow were determined using water-soluble food dyes.

Continuous vertical cores of undisturbed mire were collected varying from $300 \mathrm{~mm}$ to $1500 \mathrm{~mm}$ depth, using a sampler adapted from $130 \mathrm{~mm}$ diameter stainless steel flue pipe (pl. 1A). These cores, of both ridge and trough material, were cut into segments each $300 \mathrm{~mm}$ in length and dried to constant weight, each segment represencing $3982 \mathrm{~cm}^{3}$ of wet mire material. The abundance of Pleurophyllum hookeri on the ridges adjacent to the sample sites was mapped, using a relative scale of absent, rare, common and abundant.

The mires are extremely fragile and difficult to walk on. In many parts, they will not support a person's weight. Footprints persist as holes in the mire surface for years. Snowshoes were used to provide adequate support for walking over the mire surface, their faint impressions disappearing over a period of a few months.

\section{SURFACE TOPOGRAPHY AND MORPHOLOGY OF THE MIRES}

Surface topography and mire patterns are superimposed in figures 2 and 3 . Various relationships occur locally in both areas between pattern orientation and present surface topography. However, when viewed regionally it is apparent that pattern orientation is more or less normal to the mean terrace slope and parallel to the edge of the plateau. Within 


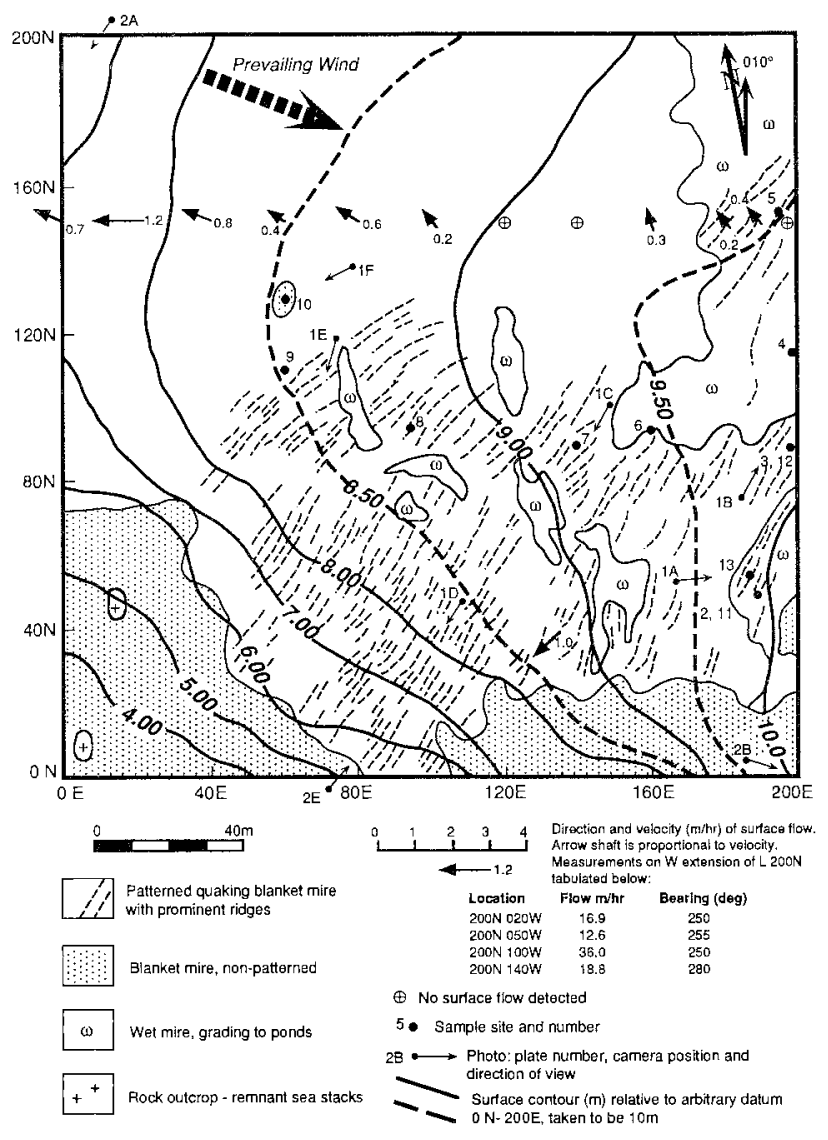

FIG. 2 - Area A: surface contours, sample locations, surface water flow data and details of mire patterns. Only the more prominent ridges are shown, drawn from air photo enlargements. Ridge patterns in the north and east of the survey area could not be reproduced accurately from the available air photographs. Note the orientation of the prevailing wind relative to the mire patterns and the variable relationship between the contours and pattern orientation. The contours were constructed from 231 surveyed points.

Area A, pattern orientations vary from $045^{\circ}$ to $055^{\circ}$. Area B is located where the plateau edge changes orientation from NNE to ENE, becoming parallel to Hasselborough Bay. There is a corresponding change in pattern orientation from $060^{\circ}$ to $085^{\circ}$, the more easterly orientations corresponding to the more easterly alignment of the plateau.

\section{Area $\mathrm{A}$}

The mire patterns comprise a series of roughly parallel ridges and troughs. Total relief between ridge and adjacent trough varies from 0.1 to $0.2 \mathrm{~m}$, the ridges being markedly drier than the intervening troughs. The water table fluctuates but normally lies at or slightly above the surface level of the troughs, which commonly contain several centimetres of water. During heavy or prolonged rain, the troughs act as gutters, channelling water off the raised mire. Trough areas which had been water filled throughout the winter of 1990 were dry after a five-day period of little rain in November.

Patches of non-patterned quaking mire also exist. They consist of irregularly shaped wet areas containing structureless mats of bryophyte vegetation, which may grade into and surround small open ponds. The wet areas are

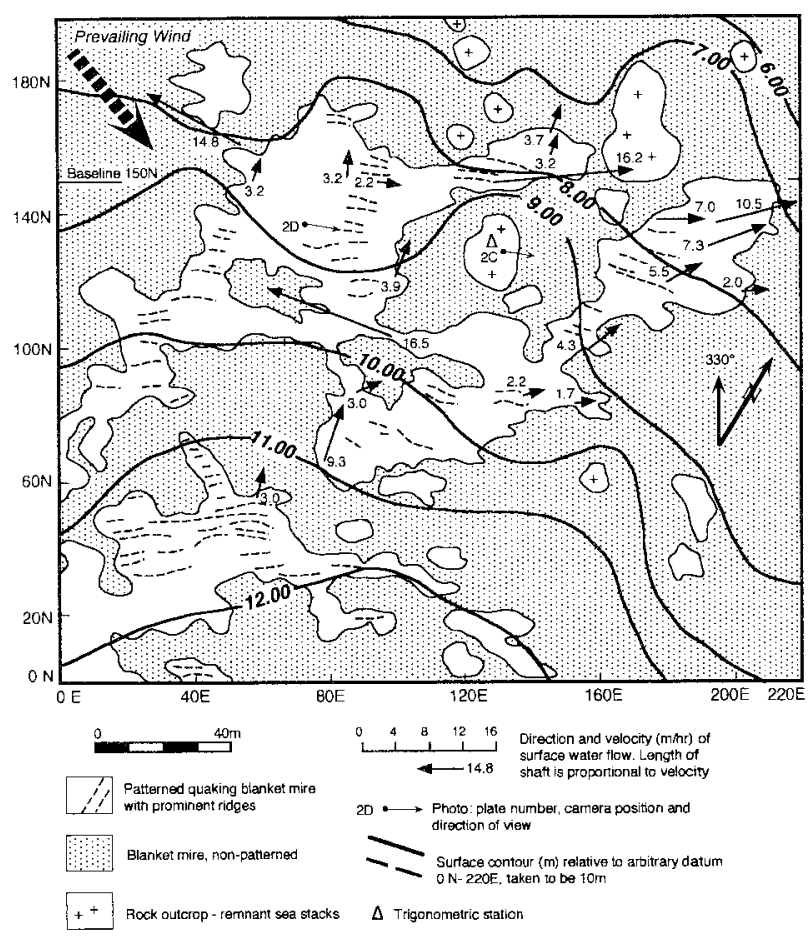

FIG. 3 - Area B: surface contours, surface water flow data, and details of mire patterns, drawn from air photo enlargements. Transition from patterned to non-patterned ground is generally sharp. Length of water flow arrows is proportional to flow rate (note: scale is $4 \times$ that in fig. 2). Local flow direction is controlled by both the ridges and the regional slope. Compared to Area A, surface slopes are steeper. As a consequence, flow rates are greater, ridges exhibit a greater tendency to be convex down slope, and there is a closer correlation between contours and pattern orientation. Contours were constructed from 245 surveyed points.

near-horizontal with contour-parallel long axes. The mats quake and provide little support, even with snowshoes. A series of such features lie parallel to the $8.5,9.0$ and $10.0 \mathrm{~m}$ contours (fig. 2, pl. 1B, C) and are interpreted to represent former areas of open water.

Wide variation in mire pattern occurs both within and between the two study areas. Patterns can be characterised on the basis of ridge length and spacing, and trough morphology. The ridges and troughs commonly display anastomosis. Troughs are defined as open where they form an interlacing network of branching and reuniting channels. There is a gradation to a pattern where it is the ridges which branch and reunite, leaving the troughs as closed linear depressions. The greatest variation occurs in Area A, as illustrated in plates 1 and 2 and diagrammatically in figure 4 , where five basic patterns have been identified. (a) Long ridges: occur adjacent to wet, non-patterned mire, characterised by long, widely-spaced parallel ridges and open troughs. Ridges in many places display continuity over $20 \mathrm{~m}$ and are separated by waterlogged troughs, which provide little support and are difficult to traverse.

(b) Open, broadly patterned mire: lateral gradation from (a) occurs typically within a distance of $10 \mathrm{~m}$. Individual ridges and troughs become shorter, typically $8-14 \mathrm{~m}$, and the 

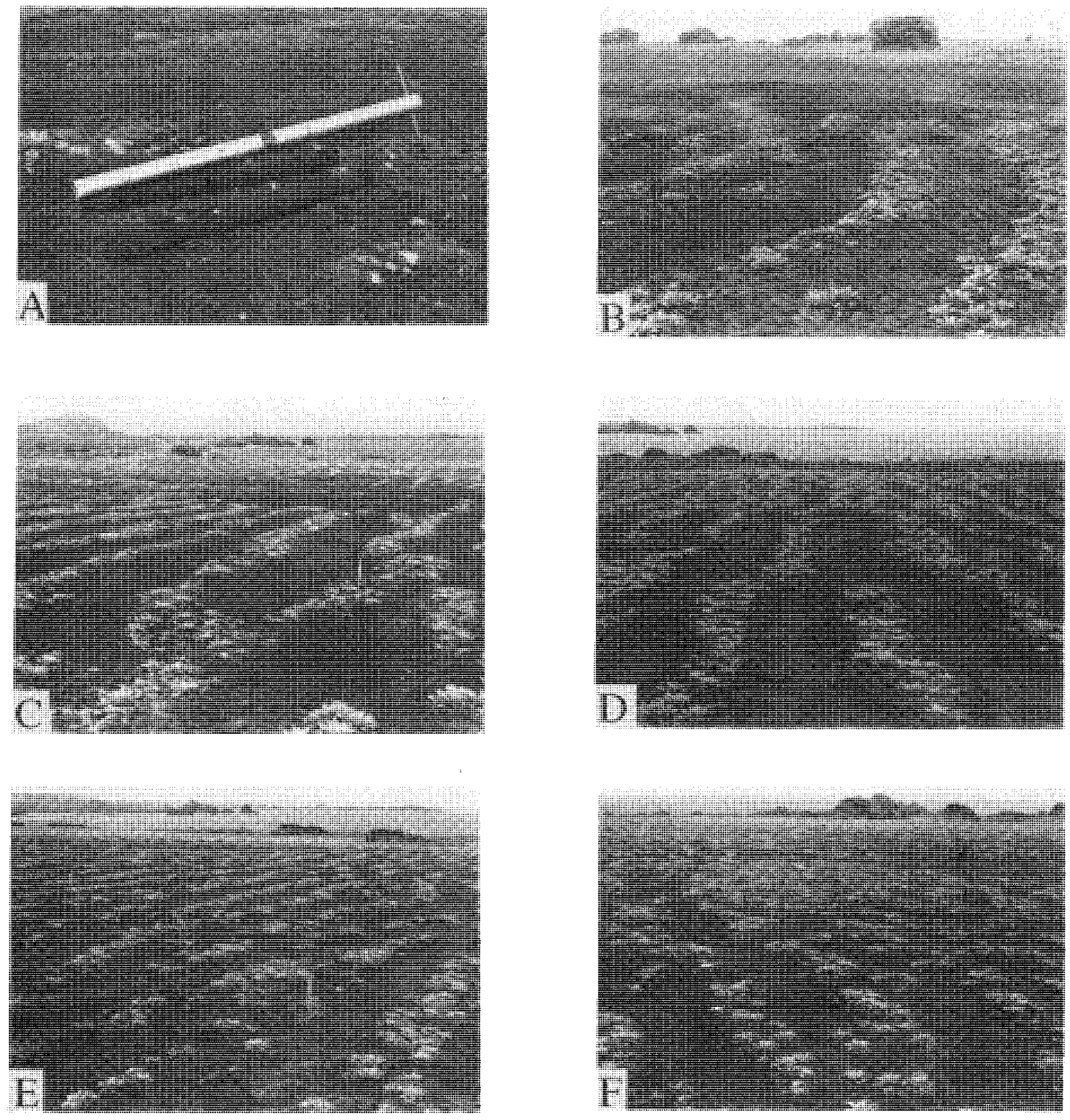

\section{PLATE I}

(A) Sampler used to collect volumetrically undisturbed samples, Area A. Cores of ridge and trough material, sample 13 a (beside sampler) and sample 136 (foreground), ready for division into $300 \mathrm{~mm}$ sample lengths.

(B) Area A, long, widely spaced ridges at $90 N 200 E$ bordering non-patterned uet mire (top and left of photo). Pleurophyllum is rare to common on the ridge to the left and common to abundant on those in the foreground.

(C) Area A, long ridges of well-developed patterned mire. Peg in middle foreground is $90 N 140 E$. Non-patterned mire in middle distance is the wet area centred at $70 N 130 \mathrm{E}$ which lies parallel to the $9.0 \mathrm{~m}$ contour (fig. 2).

(D) Area A, well-developed patterned mire, with open troughs aligned down slope and ridges accentuated by Pleurophyllum hookeri. Troughs, which normally contain several centimetres of water were dry when photos were taken in November 1990.

(E) Area A, open, tightly patterned mire. Peg in foreground is $100 \mathrm{~N} 60 \mathrm{E}$. Note that, despite the tighter row spacing, there is still downslope continuity within the troughs.

(F) Area A, tightly patterned mire in foreground, island of non-patterned mire in distance with vestigial Pleurophyllum hookeri patterns. Note that troughs have become closed, resulting in impoundment of water during heavy rain. 

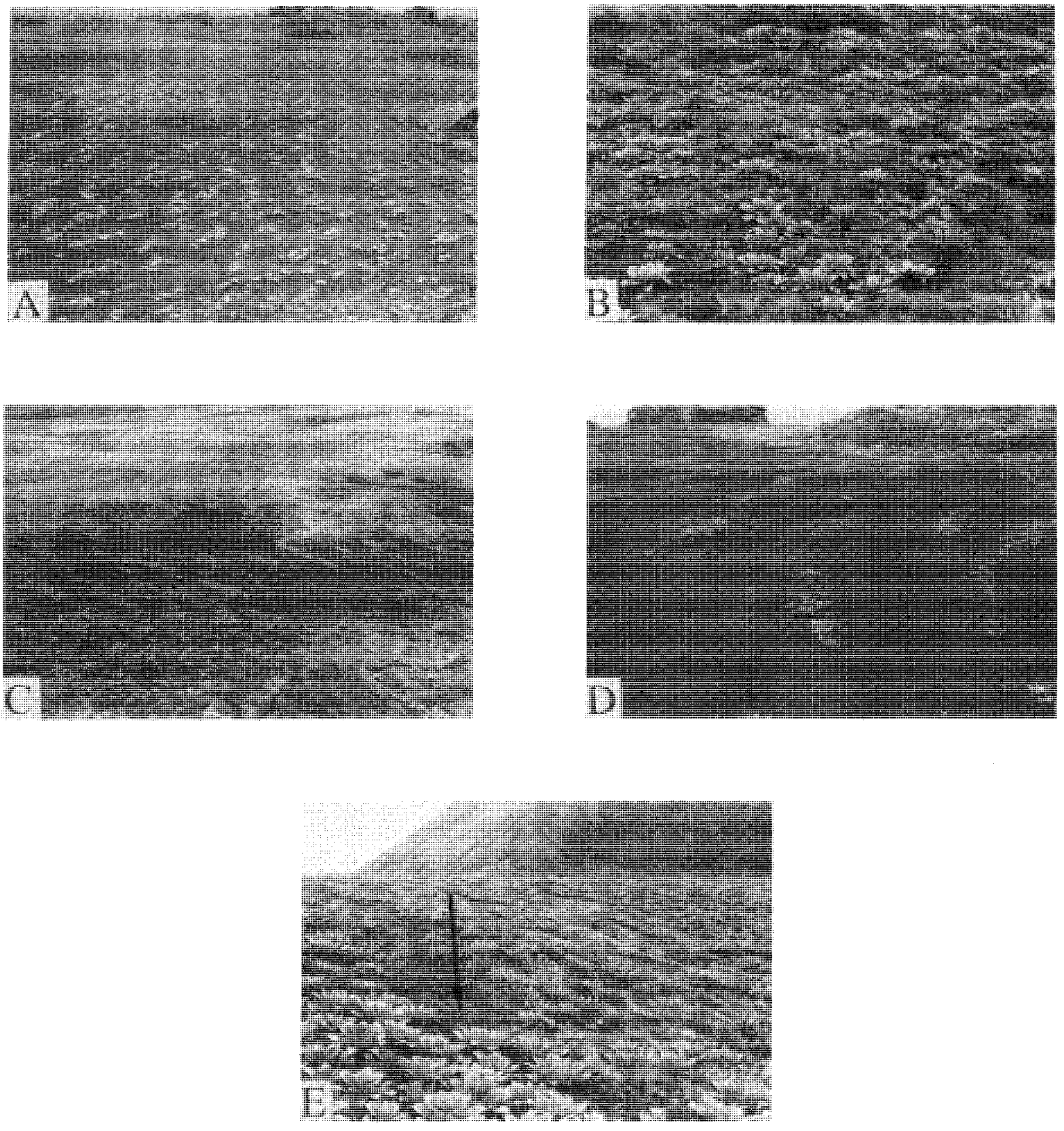

PLATE 2

(A) Diffusely patterned mire with closed troughs, sparsely colonised by Pleurophyllum hookeri. Note the narrow ridges which in most places support only single rows of Pleurophyllum.

(B) Non-patterned blanket mire, SE corner, Area A. Compared with the patterned mire, the ground is firm with a predominance of angiosperms. Pleurophyllum hookeri is more robust than on the adjacent mires.

(C) Typical patterned mire, Area B. Patterned mire occurs within small, scattered zones of very wet quaking mire surrounded by non-patterned blanket mire.

(D) Curved ridges, convex down slope, Area B. Note sea stacks in background.

(E) Ridge and trough patterns preserved along the steeply sloping southern margin of Area $A$, where patterned mire grades into non-patterned blanket mire and coastal tussock grassland. Ridges support abundant Pleurophyllum hookeri (foreground). Troughs are open, normal to slope (indicated by arrow) and channel water off the raised mire during heavy rain. Slope is 8 ". 


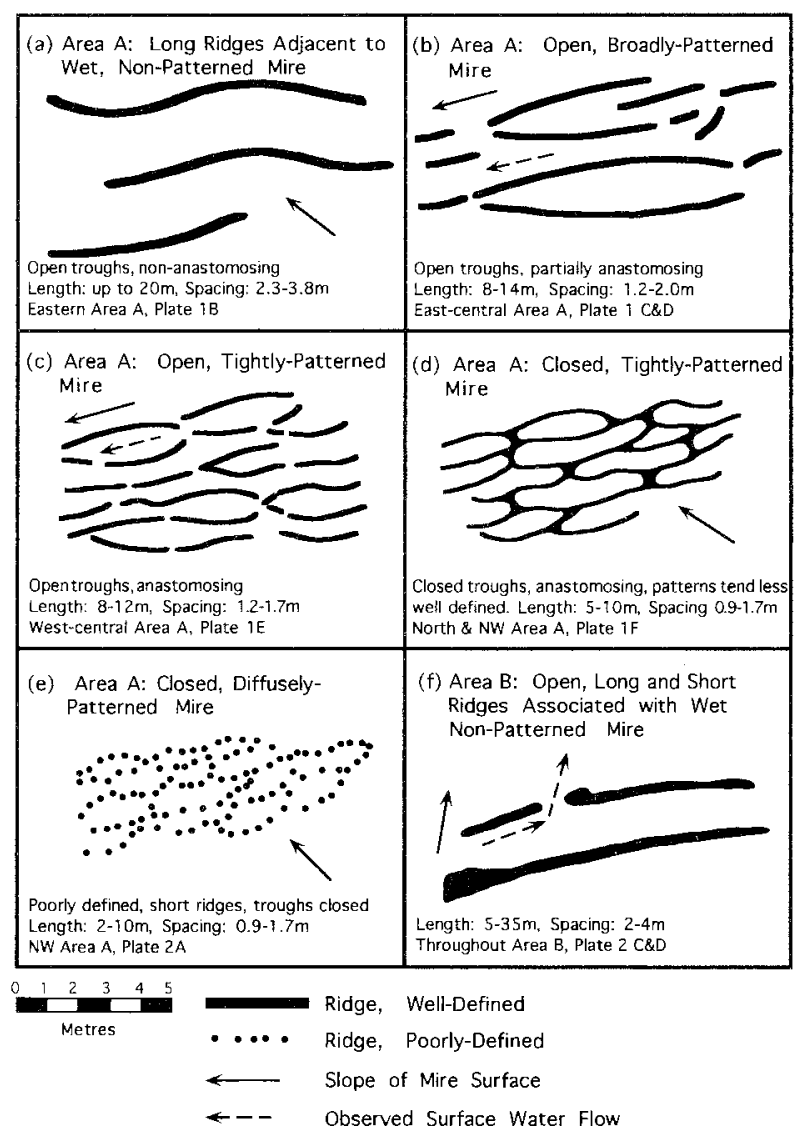

FIG. 4 - Schematic mire patterns. Area A displays a much greater diversity of patterns compared to Area B. Irregular lines $4(e)$ denote very narrow and ill defined ridges defined by clumpy development of Pleurophyllum. Ridges in Area B are often markedly convex down slope. Water is channelled laterally behind the ridges and descends through gaps to the next ridge level.

spacing between them tighter, typically about $2.0 \mathrm{~m}$. The most distinctive difference is the partial development of anastomosis. These are the typical "wind row" areas described by earlier workers.

(c) Open, tightly patterned mire: ridge spacings as close as $1.2 \mathrm{~m}$, strongly anastomosing. Where ridge spacing is greatest, troughs tend to be deeper. Surface water flows freely between the troughs during rainy periods and forms disjointed pools during drier weather.

(d) Closed, tightly patterned mire: predominant in the northwestern portion of Area A. Ridges, rather than the troughs, branch and unite, leaving the troughs isolated from each other. During periods of heavy rain, water is impounded within the troughs.

(e) Closed, diffusely patterned mire: characterised by a somewhat chaotic pattern of poorly defined but roughly linear, narrow ridges supporting sparse, clumpy Pleurophyllum. Troughs are reduced to numerous, closed, ovoid depressions.

Whereas the very long ridges bordering the wet areas are indeed "quaking" in nature, borh the ridges and troughs are noticeably firmer in the tightly patterned areas.

There are several islands of well-vegetated, non-patterned mire. The largest, locared at $130 \mathrm{~N} / 60 \mathrm{E}$, measures about $5 \times 10 \mathrm{~m}$ (fig. 2, pl. 1F). It includes what appear to be vestigial ridges, defined by diffuse linear parterns in the Pleurophyllum.

Transition from raised, quaking, patterned mire to nonpatterned blanket mire takes two forms. Around the southwestern and southern portions of the study area, the raised mire stands $2-4 \mathrm{~m}$ above the surrounding blanket mire. Here, the transition is marked by a steepening of the convex slope to about $8^{\circ}$ and a discinct change in vegetation at the foot of the slope. Frequently the ridge-trough patterns are preserved on this slope ( $\mathrm{pl}, 2 \mathrm{E}$ ) but terminate sharply at its base, which is also marked by a general increase in firmness (or decrease in werness) of the peat, increased abundance of boch Pleurophyllum hookeri and Stilbocarpa polaris, and decreased abundance of bryophytes. Along the eastern portions of the raised mire, there is frequently a sharp transition from non-patterned wer mire to firm mite, with abundant Pleurophyllum and Stilbocarpa (pl. 2B) where the slope of the blankec mire increases rowards the base of the steep plateau slopes (fig. 1).

The orientation of the ridge-trough patterns is roughly constant but varies from contour-parallel in the northeastern third of the survey area to contour-normal in the south. In general, however, most of the ridges and troughs are oriented across the contours, so that the troughs act as drains for the flow of surface water from the mire surface. Overall, Area A exhibits extremely low relief. Mean surface slopes across the surveyed grid on line $200 \mathrm{~N}$ are only $0.7^{\circ}-0.5^{\circ} \mathrm{W}$ over the $200 \mathrm{~m}$ portion of the line lying within Area A (fig. 5A). The raised nature of the mire is evident in section (fig. 5A, $C, D)$. The central portion is a gentle, convex, elongate dome trending $\mathrm{E}-\mathrm{W}$, with vertical relief of about $1 \mathrm{~m}$. This feature is defined by the $8.5-9.5 \mathrm{~m}$ contours (fig. 2).

\section{Area B}

Area B (fig. 3) contains scatrered, partially-disjointed areas of very wet quaking mire with large-scale ridges, surrounded by non-patterned mire (pl. 2C). The transition between these mire types is sharp, cypically occurring over 1-2 m horizontally. Compared with Area A, there is little variation in pattern morphology. Ridges tend to be parallel, less welldefined and vary greatly in length, with a variable spacing which averages about $3 \mathrm{~m}$ (fig. 4F). In plan, they are commonly convex down slope (fig. 3, pl. 2D). Individual ridges frequently display a stepped pattern, the top of each being slightly lower than that of the adjacent upslope ridge, resulcing in a series of very low rerraces. Water is pooled behind each ridge at levels which may differ by a few centimetres, resulting in a series of staircase ponds of very subdued vertical relief. Water may also flow laterally along a ridge until it reaches a gap where it can descend to the adjacent down slope trough (fig. $4 \mathrm{~F}$ ).

There is close correlation between mire surface slope and ridge-trough orientation. In the western half of Area B, the ridge-trough patterns and the contours borh trend about $060^{\circ}$, and in the northeastern portion of the area both the concours and the mire parterns trend about $085^{\circ}$. Slopes here are double to triple those in Area A (fig. 6). As a resulc, small variations in surface elevation during mire accretion have had a much less pronounced effect on the overall contour pattern. This is in direct contrast to Area A where subtle variations in rates of mire accretion have resulted in large differences berween parcern and contour orientation.

Non-patterned raised mire around the northern and 


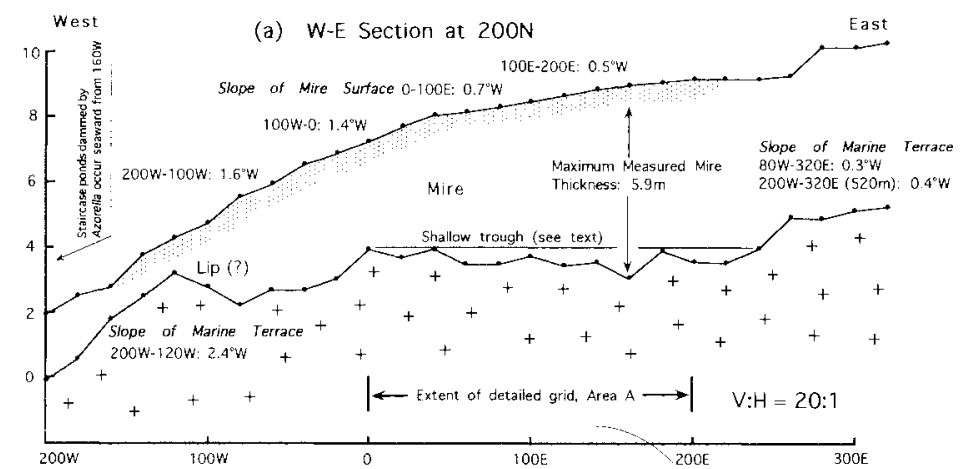

(b) W-E Section at $100 \mathrm{~N}$
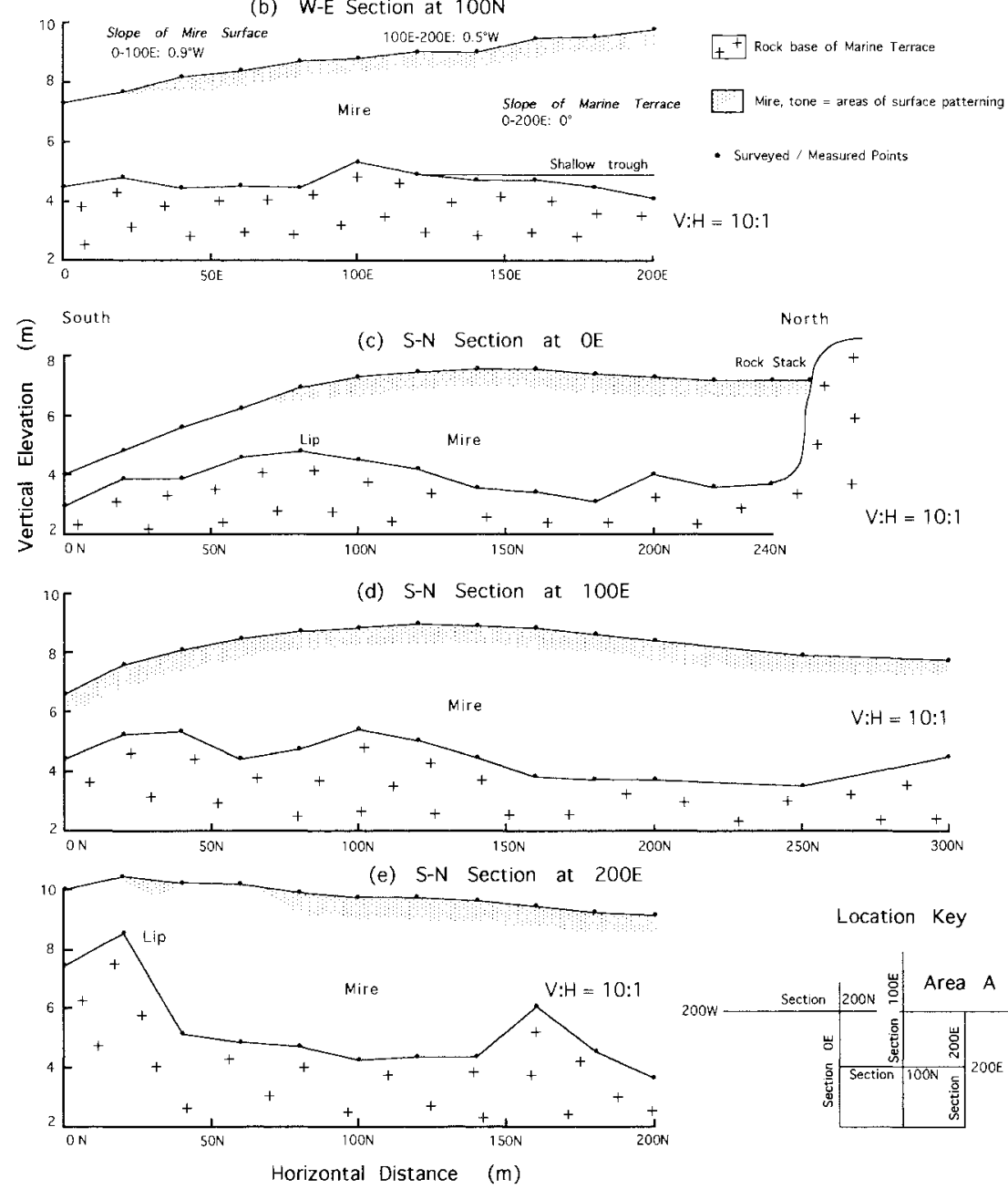

FIG. 5 - Area A: W-E and $S-N$ Sections. Around the west and south margins, the raised, patterned mire thins and drops away to non-patterned blanket mire. Note the low bedrock lip along these margins, and steep subsurface walls of the rock stack. Section $200 N$ includes the grid extensions shown in figure 1 (note the changes in horizontal scale and vertical exaggeration). The marine terrace in Sections $100 \mathrm{~N}$ and $200 N$ displays local easterly (landward) dips. Overall terrace dip however is very gently westward. Section 200N shows how both the mire surface and the terrace steepen seaward. The vertical scale exaggerates local irregularities and the convex surface of the raised mire. Elevations and distances are relative to the arbitrary datum shown in figure 1.

eastern margins grades rapidly to hummocky blanket mire. The margin of the raised mire forms a $1-3 \mathrm{~m}$ high steep bank and also defines an abrupt change in water table alticude. There is, however, little surface seepage across this boundary.

\section{SUBSURFACE TOPOGRAPHY OF THE MARINE TERRACE}

The marine terrace, where exposed in penguin rookeries elsewhere on the island consists of a very gently undulating, water-rounded beach cobble pavement over a sand and gravel substrate, rising gently to the base of the inland cliffs. Probing through the Handspike mires shows a sharp contact between overlying peat and the terrace surface, which is presumed to be similar to that observed in the rookeries.

\section{Area A}

The average slope of the marine terrace is down to the west, with numerous small irregularities (accentuated by the difference in vertical and horizontal scales used in the figures). These are best observed on L 200N (fig. 5A) where data was collected over a lateral distance of $520 \mathrm{~m}$. On $\mathrm{L} 200 \mathrm{~N}$, maximum altitude variation is only $5.4 \mathrm{~m}$ over $520 \mathrm{~m}$, with an average slope of $0.4^{\circ} \mathrm{W}$. Irregularities such as the lip at $120 \mathrm{~W}$ have a relief of only about $1 \mathrm{~m}$. The central section of the terrace is a very shallow trough (fig. 5A). The 

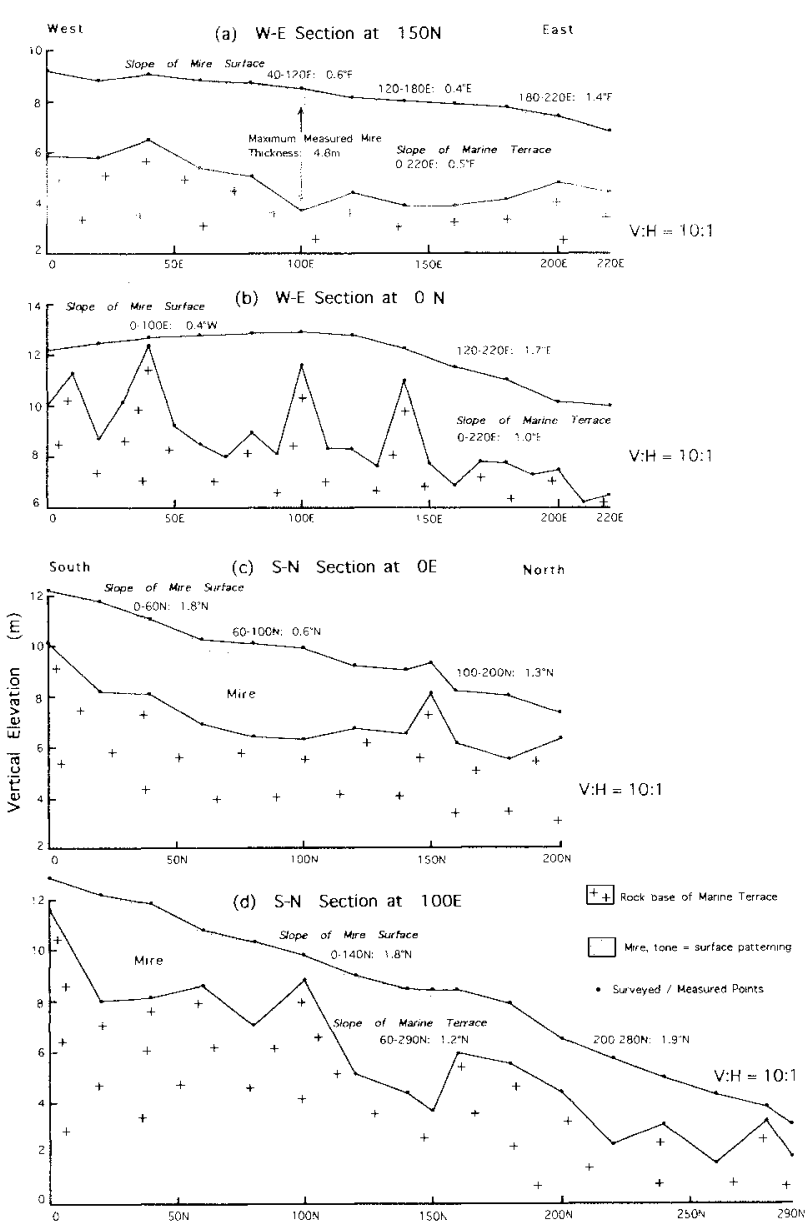

(e) S-N Section at 220

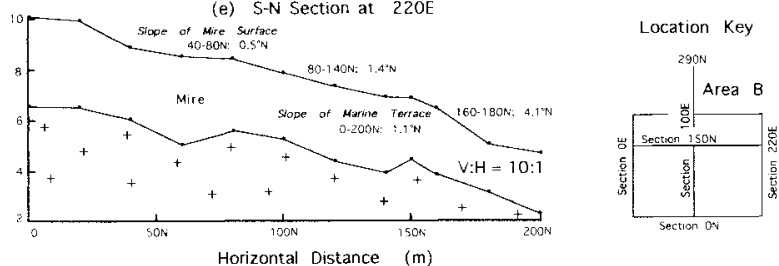

irregularities reflect minor differential crosion of bedrock by the sea, when the terrace was flooded earlier in the Holocene. While the mire surface of the detailed gridded area from $0 \mathrm{E}$ to $200 \mathrm{E}$ has wescerly dips of $0.5^{\circ}-0.7^{\circ}$, the underlying terrace has an overall easterly dip of $0.1^{\circ}$. This pattern persists on $\mathrm{L} 100 \mathrm{~N}$, with westerly surface dips of $0.9^{\circ}-$ $0.5^{\circ}$ bur an average terrace slope of $0^{\circ}$ (fig. 5B). In summary, the surface of the mire dips more steeply than the underlying marine terrace.

The mire reaches its maximum measured thickness of $5.9 \mathrm{~m}$ at $200 \mathrm{~N} / 160 \mathrm{E}$, and an average thickness of approximately $5 \mathrm{~m}$ is maintained to within $20 \mathrm{~m}$ of the plateau scarp base. On the seaward side there is a suggestion of a lip or ridge ar $120 \mathrm{~W}$. On section $100 \mathrm{~N}$ the mire reaches a maximum thickness of $5.5 \mathrm{~m}$ at $200 \mathrm{E}$. North-south profiles on lines $0 \mathrm{E}, 100 \mathrm{E}$ and $200 \mathrm{E}$ (fig. 5C-E) give the clear impression that the terrace floor below the southern edge of the mire is also slightly raised or lipped and may have acted, during the early stages of mire formation, as a natural recaining structure. This, combined with the trough noted above, suggests that, in the early phases of terrace emergence, subile natural topographic depressions may have resulted in ponding close to the base of the plateau slope. The
FIG. 6 - Area B: W-E and S-N Sections. The thickest patterned mire occurs over depressions in the marine terrace. Small sea stacks enveloped by mire are evident in Section ON. Surface and subsurface slopes tend to be steeper than those in Area $A$, and the marine terrace is much more irregular. Note how the topography of the marine terrace is frequently mimicked in the mire surface. This is most evident in the $S-N$ sections. Elevations and distances are relative to the arbitrary datum shown in figure 1.

present-day open ponds and very wet non-patterned mire discussed above, occur now over this feature. Ponding is frequently augmenced by vegetation. Fossil topography can ace as a template for initial establishment of bolster species which raise themselves into dams resulcing in significant modification of surface flow (Kirkparrick \& Gibson 1984, Whinam \& Kirkpatrick 1994). A similar process may be occurring today seaward of Area A, where numerous small staircase ponds are controlled by bolsters of Azorella macquariensis.

Rock stacks (former sea stacks) occur around the periphery of the survey area. Probing adjacent to the stacks shows that their steep sides descend more or less vercically to the terrace floor. Adjacent mires are commonly $3-4$ m thick.

\section{Area B}

The patterned mires are on average $3-4 \mathrm{~m}$ rhick (i.e. $1-2 \mathrm{~m}$ thinner than those in Area A) and exhibit a much more irregular distribution. Subsurface copography is also much more variable. The marine terrace slopes seaward at angles in excess of $1^{\circ}$, i.e. double or triple the average $0.4^{\circ}$ of 
Area A (figs 5A, 6). Here also, the distribution of patrerned mire suggests a relationship with depressions on the marine terrace. Maximum mire thickness $(4.8 \mathrm{~m})$ occurs at $150 \mathrm{~N} /$ $100 \mathrm{E}$, corresponding to the centre of the largest patch of patterned mire (fig. 6A). Similar relationships are suggested on sections $0 \mathrm{E}$ and $100 \mathrm{E}$ (fig. 6C, D). The most striking features are the numerous rock stacks which protrude through the mire (pl. 2D). These are steep to vertical sided, both above and below the mire surface. Adjacent mires, such as at $150 \mathrm{~N} / 160 \mathrm{E}$ may be up to $4 \mathrm{~m}$ thick. Many of the subsurface irregularities evident in the profiles are probably rock stacks enveloped by the growing mire.

The mire surface frequendly reflects the underlying terrace topography. High points (typically with a relief of $1-2 \mathrm{~m}$ ) on the terrace are mimicked by subtle $(<0.5 \mathrm{~m})$ features at surface. During the initial stages of terrace emergence, mire forms as thin, disjointed patches within local depressions. At the same time vegetation, particularly bryophytes, colonises the tops of rock stacks and large cobbles. Where observed today, such caps are frequently draped over the supporting structure. They are generally $<0.5 \mathrm{~m}$ thick and are presumably moisture-limited. As rock stacks are enveloped by the developing mire, their capping vegetation (particularly draped vegetation) is prematurely incorporated into the mire. The cap then commences vertical accretion (possibly in response to increased moisture) at approximatcly the same rate as the surrounding mire and is preserved as a subtle topographic high.

Depth probing data (fig. 6) indicate that the surface highs remain aligned over the original terrace features (e.g. section $0 \mathrm{E}, 150 \mathrm{~N}$, section $100 \mathrm{E}, 160-200 \mathrm{~N}$ and section $220 \mathrm{E}, 150 \mathrm{~N})$. This suggests that vertical accretion predominates over any downslope mass flow. Enveloped rock stacks which are not mimicked on the mire surface probably had little or no capping vegetation.

\section{HYDROLOGY}

Mire hydrology is doubtless a complex relationship berween terrace and surface slopes, minor surface irregularities such as the ridges and troughs, the internal morphology and hydraulic conducrivity of the mire peats, rainfall, evaporation and transpiration. The mires appear to be predominantly ombrotrophic and act as giant sponges, holding vast quantities of water through capillary action and adsorption to colloids (Ivanov 1981).

Surface flow tests in Area A were carried out on L $150 \mathrm{~N}$ in May 1990 when the troughs were water-filled. Here the slopes are low and the ridge-trough patterns are approximately contour-parallel (fig. 4D, E typifies this situation). Dye $(10 \mathrm{ml})$, placed in the centre of a trough, flowed laterally, becoming impounded against the ridge on the downslope side. Eventually traces of dye would appear in the adjacent downslope trough, having flowed through the peats of the incervening ridge. Flows were found to be roughly normal to the surveyed contours, bur the relatively low surface slopes and the necessity for the water to flow through the ridges impeded the flow and resulted in average flow rares which varied from negligiblc to $1.2 \mathrm{~m} \mathrm{hr}^{-1}$ (fig. 2). Further west, where the mire slopes more steeply towards the coastal ponds, water flows visibly along the troughs. Dye tests on L $200 \mathrm{~N}$, west of the survey area, indicated surface flow rates of up to $36 \mathrm{~m} \mathrm{hr}^{-1}$. Local surface slopes here are up to $3.7^{\circ}$ west. A single test was carried out at
$40 \mathrm{~N} / 135 \mathrm{E}$ (fig. 2), where the contours are oriented $70^{\circ}$ to the ridge-trough patterns. Run-off from early morning rain was flowing visibly in the more steeply sloping troughs around the southern periphery of the mire (pl. 2E). However, at the test site there was no visible flow. Standing water in the trough was $10-20 \mathrm{~mm}$ deep. Over 50 minutes, dye placed in the centre of the trough traced a curving flow path, finally becoming impounded against the west side of the trough, $800 \mathrm{~mm}$ down slope of the start point, ar a flow rate of $1.0 \mathrm{~m} \mathrm{hr}^{-1}$. This confirmed that flow direction is controlled both by the subtle surface slopes and the troughs, which effectively act as gutters forcing flow at various angles to the contours. Much more extreme examples of this occur in Area B where the increased gradient is evident in the flow races (measured in June 1990), which varied from 1.6 to $16 \mathrm{~m} \mathrm{hr}^{-1}$, both parallel to and across the ridge-trough patterns (figs $3,4 \mathrm{~F}$ ).

Peat comprising the ridges exhibits a considerable resistance to the lateral subsurface flow of water. In a simple test, three $0.5 \mathrm{~m}$ deep, verrical-walled pirs were dug in ridged mire at sample sites 11,12 and 13. The adjacent troughs, lying approximately a metre either side, were water logged and contained standing water. The pits took 5 to 10 minutes to fill. Water trickled slowly down the pit walls and also appeared to be moving vertically up through the pit floor. The hydraulic conductivity of the ridge peats is clearly lower than that of the rough peats. The ridges impede the surface and near surface flow of water off the mire. Therefore, during heavy rains troughs act as gutters, channelling water to the edge of the mire.

\section{SURFACE PEAT SAMPLING}

Peat is taken to include living surface vegetation plus dead and decaying plant tissues comprising the mires. It is evident to anyone walking on the mires that the ridges are much denser than the troughs. The ridges support a person while the troughs often do not. Depth probing through adjacenr ridge trough sets showed the same thing and provided the initial evidence that the surface patterns persisted at depth as density differences.

Undisturbed $300 \mathrm{~mm}$ long peat cores were collected from sites in Area A (fig. 2, table 1). Samples were collected from non-patterned mire, wet non-patterned mire and from a number of different sites in the patterned mires, where sample sets (designated a and b) were collected from adjacent ridges and troughs. Distance between ridge centres and average ridge length was measured, plus the relative abundance of Pleurophyllum hookeri. The bulk density of peat (dry weight per unit fresh volume, including voids, expressed as $\% \mathrm{w} / \mathrm{v}$ ) provides a measure of peat density. It is also a relative measure of the degree of decomposition (Chason \& Siegel 1986) and is inversely proportional to hydraulic conductivity (Boelter 1969). Handspike values range from $2.5 \%$ to $6.6 \%$ implying $93.4 \%$ to $97.5 \%$ water. These figures are in agreement with the $91 \%$ to $98 \%$ quoted by Ivanov (1981).

Peats from long ridges (fig. 4A, samples $2 \mathrm{a}, 3 \mathrm{a}, 11 \mathrm{a}, 12 \mathrm{a}$, 13a), occurring adjacent to wer non-patterned mire, have bulk densities which are generally greater than rhose from ridges in the more tightly patterned mire (fig. $4 \mathrm{~B}, \mathrm{C}$, samples 6a, 7a, 8a, 9a). Corresponding values for trough peats are less (sample $5 \mathrm{a}$ is an obvious exception). The data set is small but suggests that the large ridge-trough sets are 
TABLE 1

Results of Surface Sampling, Area A

\begin{tabular}{|c|c|c|c|c|c|c|c|c|c|c|c|}
\hline \multirow[t]{2}{*}{ Sample* } & \multicolumn{2}{|c|}{ Location } & \multicolumn{2}{|c|}{ Ridge Peat } & \multicolumn{2}{|c|}{ Trough Peat } & \multirow[t]{2}{*}{$\mathrm{T} / \mathrm{R}^{ \pm}$} & \multirow{2}{*}{$\begin{array}{l}\text { Width } \$ \\
(\mathrm{~m})\end{array}$} & \multirow{2}{*}{$\begin{array}{l}\mathrm{L}^{\prime} \\
(\mathrm{m})\end{array}$} & \multirow[t]{2}{*}{$\mathrm{Plr}^{*}$} & \multirow[t]{2}{*}{ Comments } \\
\hline & & & Total $^{\dagger}$ & $\%(w / v)$ & Tocal $^{\dagger}$ & $\%(w / v)$ & & & & & \\
\hline 1 & $000 \mathrm{~N}$ & $200 \mathrm{E}$ & 264 & 6.6 & & & & & & 3 & Non-patterned blanket mire \\
\hline $2 a-2 b$ & $050 \mathrm{~N}$ & $190 \mathrm{E}$ & 246 & 6.2 & 101 & 2.5 & 0.40 & $2.0-2.3$ & 10 & 1 & Large sinuous ridges adjacent \\
\hline $11 a-11 b$ & $050 \mathrm{~N}$ & $190 \mathrm{E}$ & 262 & 6.6 & 144 & 3.6 & 0.55 & $2.0-2.3$ & 10 & 1 & to non-patterned wet mire \\
\hline $\begin{array}{l}3 a-3 b \\
\text { of }\end{array}$ & $090 \mathrm{~N}$ & $200 \mathrm{E}$ & 235 & 5.9 & 99 & 2.5 & 0.42 & $1.8-2.3$ & 10 & 2 & Large sinuous ridges south \\
\hline $12 a-12 b$ & $090 \mathrm{~N}$ & $200 \mathrm{E}$ & 205 & 5.2 & 159 & 4.0 & 0.77 & $1.8-2.3$ & 10 & 2 & non-patterned wet mire \\
\hline 4 & $115 \mathrm{~N}$ & $200 \mathrm{E}$ & & & 127 & 3.2 & & & & 0 & Non-patterned wet mire \\
\hline $5 a-5 b$ & $154 \mathrm{~N}$ & $195 \mathrm{E}$ & 194 & 4.9 & 122 & 3.1 & 0.63 & $2.3-3.8$ & 20 & 2 & $\begin{array}{l}\text { Long ridges between areas of } \\
\text { non-patterned wet mire }\end{array}$ \\
\hline $6 a-6 b$ & $095 \mathrm{~N}$ & $160 \mathrm{E}$ & 216 & 5.4 & 194 & 4.8 & 0.88 & $1.6-2.1$ & 8 & $1-3$ & $\begin{array}{l}\text { Well developed ridges, } \\
\text { Pleurophyllum rare to } \\
\text { abundant }\end{array}$ \\
\hline $7 a-7 b$ & $090 \mathrm{~N}$ & $140 \mathrm{E}$ & 203 & 5.1 & 163 & 4.1 & 0.80 & $1.2-1.9$ & 14 & 3 & $\begin{array}{l}\text { Very well developed even } \\
\text { ridges }\end{array}$ \\
\hline $8 a-8 b$ & $095 \mathrm{~N}$ & $095 \mathrm{E}$ & 225 & 5.6 & 189 & 4.8 & 0.84 & $1.2-1.5$ & 12 & 3 & $\begin{array}{l}\text { Indistinct ridges, partially } \\
\text { fused, troughs weak to absent }\end{array}$ \\
\hline $9 a-9 b$ & $110 \mathrm{~N}$ & $060 \mathrm{E}$ & 204 & 5.1 & 172 & 4.3 & 0.84 & $0.9-1.7$ & 9 & 3 & $\begin{array}{l}\text { Ridges short, anastomosing. } \\
\text { Pleurophyllum abundant } \\
\text { and vigorous }\end{array}$ \\
\hline 10 & $130 \mathrm{~N}$ & $060 \mathrm{E}$ & 212 & 5.3 & & & & & & 3 & $\begin{array}{l}\text { Island of non-patterned } \\
\text { mire, Pleurophyllum in } \\
\text { vestigial rows }\end{array}$ \\
\hline $13 a-13 b$ & $055 \mathrm{~N}$ & $188 \mathrm{E}$ & 218 & 5.5 & 103 & 2.6 & 0.47 & $2.0-2.3$ & 10 & 2 & $\begin{array}{l}\text { Large sinuous ridges adjacent } \\
\text { to non-patterned wet mire }\end{array}$ \\
\hline
\end{tabular}

* All samples are $0-300 \mathrm{~mm}$ in depth, a-b sample sers are ridge-trough pairs. Single sample numbers are from non-patterned mires. Samples $11 \mathrm{a}-11 \mathrm{~b}, 12 \mathrm{a}-12 \mathrm{~b}$ and $13 \mathrm{a}-13 \mathrm{~b}$ represent the top portions of the deep profiles.

$\dagger$ Total (Ridge/Trough Peat) means dry weight of volumetrically undisturbed $3982 \mathrm{~cm}^{3} \mathrm{sample}, \%$ (w/v) means bulk density (dry weight of volumetrically undisturbed $3982 \mathrm{~cm}^{3}$ sample expressed as a percentage of the weight of the original volume, S.G. peat taken to be 1.0 ).

$\neq T / R=$ ratio by weight of organic material in trough to that in ridge.

$\$$ Width = spacing between ridge centres.

' $\mathrm{L}=$ maximum ridge length.

\# $\mathrm{Pl}$ r = relative measure of colonisation by Pleurophyllum hookeri, adjacent to sample site; 0 : absent, 1 : rare, 2 : common, 3 : abundant. 
generally more physically variable. This is best reflected in their trough:ridge bulk density ratios which vary from 0.40 to 0.77 (table 1). The ridge peats have bulk densities which approach that of non-parterned blanket mire (sample 1).

Pleurophyllum was mapped as abundant only in samples 6 to 9 . Interestingly, these have ridge bulk densities considerably lower than the large-scale wet area features, but trough bulk densities which are much higher. Only these four samples have trough:ridge peat density ratios of 0.8 or greater (table 1). By comparison, Pleurophyllum growth is rare around the sites of samples $2 \mathrm{a}$ and $11 \mathrm{a}$, with trough:ridge peat density ratios of 0.4 and 0.55 , despite the fact that they have ridge bulk densities similar to nonpatterned blanket mire (sample 1), which supports abundant Pleurophyllum. The relationship between ridge:trough peat density, ridge spacing and Pleurophyllum colonisation is illustrated in figure 7.

\section{DEEP SAMPLING}

The surface sampling demonstrated distinct differences in bulk density between ridge and trough peats. It remained unclear, however, whether the ridge-trough patrerns were merely a recent surface phenomenon or features which

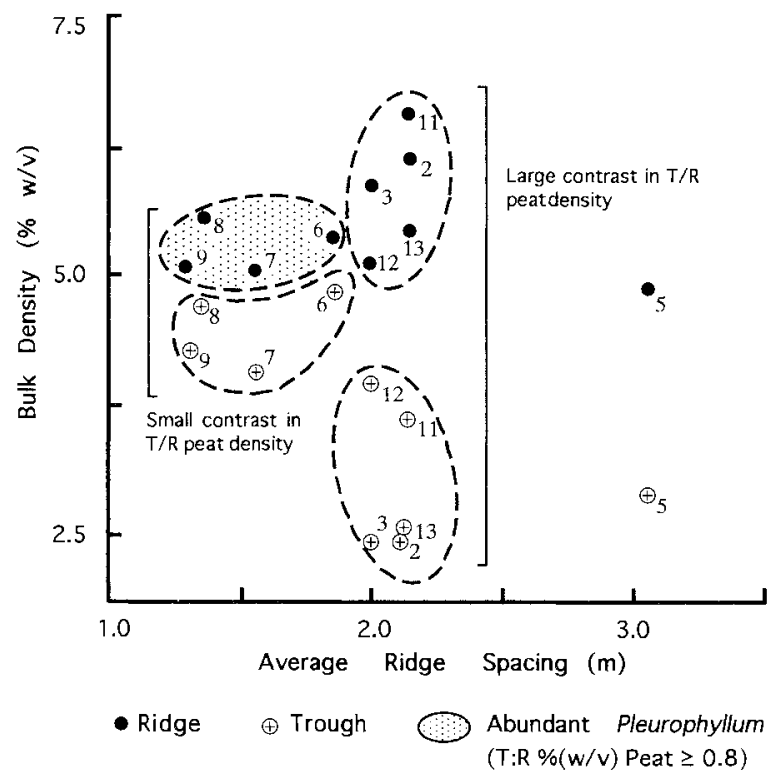

FIG. 7 - Area A: density of the peat below the ridges and troughs, surface to $300 \mathrm{~mm}$ depth, expressed as weight (\% w/v), plotted against average ridge spacing. Ridge spacing may be taken as a relative measure of wetness, since the wider spaced ridges tend to occur in wetter areas, in particular adjacent to areas of non-patterned mire. As ridges become closer spaced, the ridge and trough peat densities approach each other. Pleurophyllum hookeri is most abundant on the closely spaced ridges (samples 6-9). While these do not necessarily exhibit the highest ridge peat densities, they do have the highest trough peat densities. Pleurophyllum vigour appears to be related to reduced waterlogging and increased water-level regulation, which enhances peat production and reduces the contrast between trough-ridge peat densities. As a result, ridges with the highest peat densities do not necessarily support abundant Pleurophyllum. persisted at depth, reflecting former mire morphology. Initially, two $900 \mathrm{~mm}$ long cores (samples $11 \mathrm{a}$, b) were obtained from a ridge-trough set previously sampled to $300 \mathrm{~mm}$ (samples $2 \mathrm{a}, \mathrm{b}$ ). The core was cut into three equal $300 \mathrm{~mm}$ sections and dried to constant weight. The results (fig. 8A) showed that the density difference between ridge and trough was preserved to $900 \mathrm{~mm}$. A larger sampler was constructed and four continuous cores (samples 12a, b, and $13 \mathrm{a}, \mathrm{b}$ ) were obtained from two additional trough-ridge sets to a deprh of $1500 \mathrm{~mm}$ (pl. 1A). Cores from the ridges had a firm texture and retained their shape when removed from the sampler. In contrast, cores from the troughs had less integrity and included brown gelatinous material, possibly indicative of organic colloids. Figure $8 \mathrm{~B}, \mathrm{C}$ shows that the differences in ridge:trough peat densiries are preserved, at least to $1500 \mathrm{~mm}$ below the present surface.

There is, overall, a symmetry in the patterns between individual ridges and troughs. In samples $12 \mathrm{a}, \mathrm{b}$, vegetation density decreases to $600 \mathrm{~mm}$, followed by a rapid increase and possible stabilisation below $1200 \mathrm{~mm}$. In samples 13a, $\mathrm{b}$, a pattern of increasing and decreasing densities is mimicked from 900 to $1500 \mathrm{~mm}$. A general increase in density due to compression might be expected, and it is nor clear why these larger vertical variations should occur. Chason \& Siegel (1986) described similar variations in

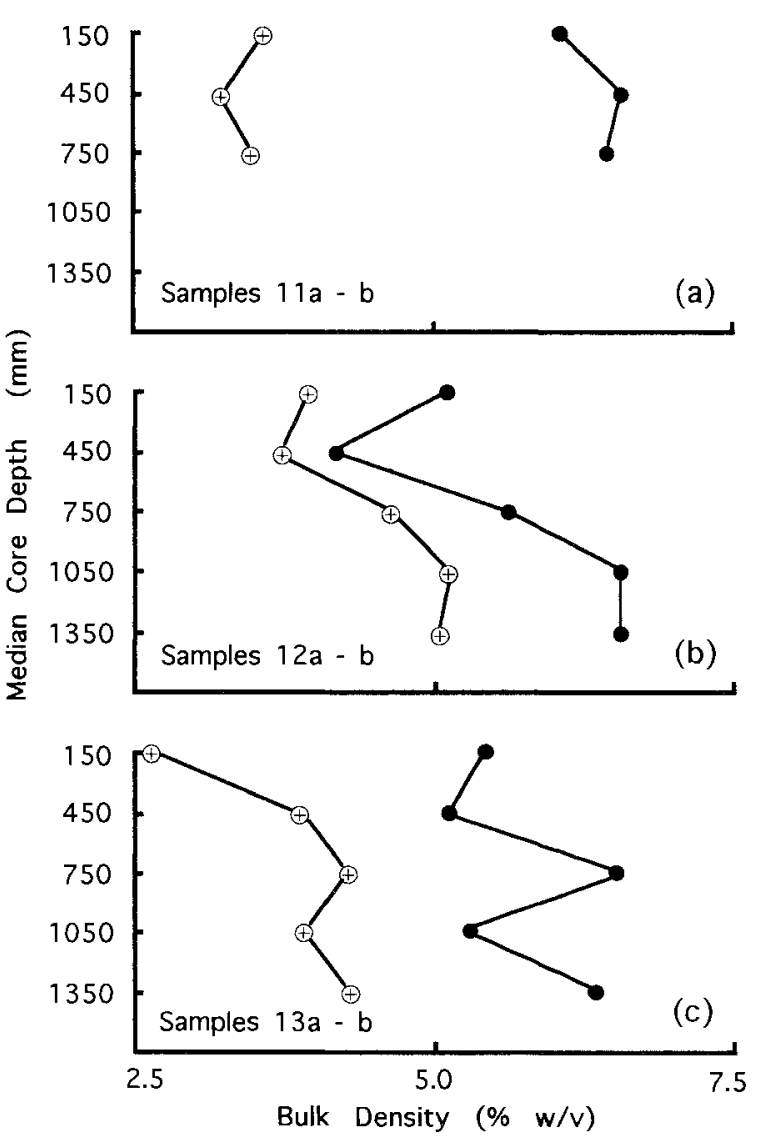

- Ridge $\oplus$ Trough

FIG. 8-Area A: comparison of ridge/trough peat densities, deep sampling profiles. Note that in samples 12 and 13 the vertical variations in density are mimicked in both the ridge and adjacent trough. Depths indicate the median of each $300 \mathrm{~mm}$ sampling interval. 
bogs and fens which they interpreted as differences in the degree of decomposition. Such variations may represent variations in mire development over time. The reduction in ridge density just below the surface may reflect a condition similar to that occurring in fearherbed (Selkirk et al. 1990a), where the uppermost layers of the mire float on near surface water lenses.

\section{DISCUSSION}

Mire ecologists have long recognised that peat profiles comprise two principal zones. The terms acrotelm and catotelm for the upper and lower horizons were introduced by Ingram (1978). The acrotelm is the aerated surface zone composed of living and undecomposed planc material and within which the water table fluctuates. This is the peatforming layer within which aerobic bacteria and other organisms break down dead plant material. Its base is generally taken to be the lower limit of water table fluctuation. The main body of the mire is the catotelm, permanently waterlogged and anaerobic, within which biochemical processes proceed very slowly. In a patterned mire the acrotelm and catotelm can be further divided into ridge and trough. The physical properties of all four components will differ. At Handspike, extremes of water table fluctuation are estimated to be about $0.3 \mathrm{~m}$, representing a range from the tops of the ridges to about $0.1 \mathrm{~m}$ below the base of the troughs. These figures also are the approximate thicknesses of the ridge and trough acrotelm respectively.

\section{Orientation of the Patterns Relative to the Surface Contours}

Apart from their distinctive surface patterns, it was the variation in the slope/pattern orientation which prompted interest in the Handspike mires. All patterned mires form either on very gentle slopes or develop their own sloping surface as a result of peat accretion (Moore \& Bellamy 1974). Patterning displays a consistent tendency towards alignment parallel to the prevailing contours (Sjors 1961). It appears probable, therefore, that during their initial development, the Handspike mire patterns were contourparallel. This accords with their overall orientation, which is roughly parallel to the plateau scarp.

We would expect that the initiation of doming would be accompanied by a tendency for the patterns to maintain a contour-parallel orientation by aligning themselves around" the dome. At Area A, quite the opposice appears ro have occurred. The patterns have retained their original orientation and now lie, with apparent stability, at angles to the contours. This suggests some advantage in this unusual alignment.

\section{Pattern Orientation and Water Level Regulation}

Stabilicy in mires results in the maximum development of both plant associations and peat (Ivanov 1981). Mire plants can tolerate only very limited deviations of the water table. Therefore, in mires, stability requires that water levels be maintained within strict limits of fluctuation and that mechanisms exist whereby fluctuations, under normal conditions, are restricted and, under extreme conditions, are broughe quickly back within limits. In a non-patterned mire, this stability is achieved through the vertical distribution of living, dead and decomposing material within the acrorclm where, between the rop and botrom, hydraulic conductivicy may decrease by several orders of magnitude (Ivanov 1981: 198, Rycroft et al. 1975). This has the effect of progressively allowing more or less water to flow as levels rise and fall, and maintaining water levels within a limited range most of the time (Damman \& Dowhan 1981).

A parterned mire is more complex and includes a wider variety of plant associations than the simple blanket mire. Stability requires mechanisms which allow different quantities of water through the acrotelm, while maintaining the optimum water table level for each plant association (Ivanov 1981). Consider the case where patterns lie at some angle (other than $90^{\circ}$ ) to the contours. When rainfall is excessive, the water table rises above the surface level of the troughs. Open troughs then provide direct, uninterrupted surface drainage to the edge of the mire. Under these condirions, the troughs act as gutters and are capable of very efficiently shedding large quantities of water from the mire surface. When rainfall is less, the water table falls and troughs become a series of water-filled elongate basins. Drainage at this level occurs in a series of steps, easily and rapidly along the trough as surface water, and then more slowly through the ridge acrotelm (as ground water) and into the adjacent trough as surface water. The rate of water flow is high becausc most occurs within the troughs as surface flow, impeded only by bottom friction and wind. Flow through the ridges is slower, but the dye tests confirm that the hydraulic conductivity of the ridge acrotelm peats is very high. The flow path is therefore a zigzag series of long (trough) and short (ridge) steps, which overall describe a parh oblique to the ideal contour-normal flowlines.

When the troughs cease to contain any surface water, all drainage will occur as ground water. Flow will continue to be biased along the troughs where the near surface acrorelm peats have the highest hydraulic conductivities. With further lack of precipitation, the rate of seepage will continue to decrease, as water levels fall. There will be some critical level which can be sustained temporarily. Lower levels may induce changes in the ridge-trough vegetation. Such a regulation mechanism provides continuously variable waterlevel regulation, controlled principally by the proportion of standing water in the troughs.

Precipitation on Macquarie Island is recorded on an average of 308 days per year (Streten 1988). Under such conditions, the ability to shed surplus surface water quickly may be advantageous to plants growing on the mire. Meteorological data from the Bureau of Meteorology station $(3.5 \mathrm{~km}$ cast of the ficld site - fig. 1) suggests that surplus water can be effecrively shed over several days. During winter 1990, troughs were consistently water-filled. During heavy rain, water was frequently observed being channelled off the mire. October 1990 was abnormally wet $(116.8 \mathrm{~mm}$, monthly average $71.6 \mathrm{~mm}$ ) and from $1-15$ November $1990,45 \mathrm{~mm}$ of rain fell (monthly average $68.2 \mathrm{~mm}$ ), including $34.8 \mathrm{~mm}$ over the period10-15 November, followed by 5 "dry" days ( $0.2 \mathrm{~mm}$ rain on 17 November). Despite the recent abundant rain, the troughs were dry when photographed for this paper, on 20 November (che period 16-23 November was the longest dry spell of the year). 


\section{Colonisation of the Patterned Mires by Pleurophyllum hookeri}

Pleurophyllum appears to be well suited for growth on a mire undergoing vertical accretion. Air canals in the roots vary with the degree of waterlogging (Jenkin \& Ashion 1979). Contractile stems maintain the leaf rosettes at the mire surface, while the vertical growth of the stem keeps pace with mire accretion. However, plants growing on the patterned mires are small, compared to those growing on the adjacent and better drained blanket mires. Vigour clearly decreases with increased waterlogging. Jenkin \& Ashton (1979) note that plant size may vary by an order of magnitude between poor and favourable sites. Interestingly, however, similar root morphology was displayed by Pleurophyllum collected from ridges within the patterned mire and from adjacent blanket mire. In both areas, vertical rhizomes in marure plants were growing to about $0.35 \mathrm{~m}$ depth, with decayed tissue extending beyond $0.40 \mathrm{~m}$.

The data suggest that Pleurophyllum has colonised the ridges simply because they are drier than the troughs, and preferentially where the contrast between trough and ridge pear bulk density is low (the current study suggests a threshold ratio of 0.8 ). Ridges with denser peat will have the capacity to maintain water through capillary forces at higher elevations than ridges of less dense peat. Under normal conditions, therefore, the local water table (and waterlogging) will be lower in ridges containing lower density peats.

Similarly, troughs with a higher peat density will release water less easily to ridge capillary succion (when there is no free water in the troughs) than will troughs with lower peat densities. Clearly, ridges with somewhat lower pear density and troughs with higher peat density, when combined, produce condirions where the local level of waterlogging is reduced.

Pattern orientation also appears to be important. Where ridges are contour-parallel, they act as local dams. Surface water is pooled behind each ridge in the form of elongate staircase ponds. Water flow is predominantly through the ridge pears, and the internal ridge water table will be dominated by the higher levels in the upslope trough. In contrast, a ridge which is contour-normal is a local ground water mound, and adjacent water-filled troughs constitute constant head boundaries. During rain, local seepage within such a ridge will not follow the regional flowline down the ridge axis, but instead will be concour-parallel, directly into the adjacent troughs. These ridges will be far better drained than those which are contour-parallel. Higher trough peat densities in the contour-normal patterns may reflect enhanced growing conditions and increased peat production, resulting from hetter water-level regulation, which occurs where the patterns are most effectively aligned as surface drains. The degree of Pleurophyllum colonisation may be related both to the density of the ridge-trough pears and pattern orientation.

Glaser et al. (1981) described vegetational changes in patterned mires subjected to altered hydrological conditions. Where the water table was locally controlled by agricultural drainage ditches, strings (ridges) became higher and wider and colonisation by tree species commenced, although the basic string-flark patterns were preserved. Where the mire (and its water supply) was cut by a highway, patterned mire downslope disappeared.

\section{Early Mire Development}

The extent to which local basins on the underlying terrace may have influenced early mire development remains speculative. The area underlying the eastern portion of Area A may have been a large pond on the newly emergent terrace. Such ponds are frequencly preserved in raised mires, being carried upwards as the mire develops (Moore \& Bellamy 1974). Remnant wet areas common in Area A may represen the final vesriges of this feature. The early mire would have been horizontal, initially expanding over the open water, but would have developed its own slope as the mire grew and expanded seaward on the emerging terrace. Initial ponding may have been aided by bolster species such as Azorellat macquariensis which are considered to be pioneer species (Selkirk et al. 1988). Similar ponding aided by Azorella can be observed on the recently-emerged terrace between the beach and the raised mire west of Area $A$. As Macquarie Island continues to rise and further expose the coastal terrace, the raised mire may concinue to expand westwards.

The mire in Area A resembles forms described from the Northern Hemisphere, including maritime sloping-plateau eccentric bogs of North America (Glaser \& Janssens 1986) and eccentric domed mires of the Baltic region of Northern Europe (Moore \& Bellamy 1974). The latter form initially in small basins on sloping ground, frequently within steepersided valleys, the peats eventually overflowing the small primary basins. Water supply is greatest up the slope against the steeper valley walls. Here, preferential upward growth competes with gravity acting down slope, resulting in an eccentric dome of peat. Elongated curvilinear hummocks, separated by elongate sinuous pools, develop contourparallel around the cupola. This bears similarities to the Handspike mires where development may have becn initiated in depressions on the sloping marine terrace, the only difference being that early accretion may have been more uniform, with roughly consistently oriented patterns developing prior to late stage doming and eccentricity.

The relationships between slope and pattern spacing provide further evidence that the patterns pre-dare doming. Patcerned mires and bogs display an inverse relationship between slope and pattern density. In the aapamires of the boreal and subarctic peatfands, the distance berween ridges may vary from a few metres on steep ground to greater than a hundred metres on almost horizontal ground (Sjors 1961 , Heinselman 1965, Grittinger 1970, Washburn 1979, Foster et al. 1983). At Handspike Point, pattern spacings of typically $3 \mathrm{~m}$ occur in Area B on slopes which are double to triple those in Area A. In Area B, there is a similarity berween terrace and surface slopes, implying a more or less uniform rate of accretion over the mire. This is in direct contrast to Area A, where pattern spacings less than $3 \mathrm{~m}$ occur on (comparatively) much shallower slopes. This is the opposite of what would be expected and suggests that, when pattern development commenced, surface slopes in Area A, were probably similar to those currently observed in Area B. The fact that patterns are preserved on the mire surface despite changes in slope and slope orientation suggests either that mire accretion occurs at a more rapid rate than the ability of the patcerns to adjust or, as suggested earlier, the new orientations provide unexpected benefits, such as enhanced warer-level stability. 


\section{Internal Structure and Hydrology}

Within mires generally, the acrotelm is very thin compared to the catotelm, and hydraulic conductivities may decrease by many orders of magnitude between the top of the acrotelm and the catorelm (Boelter 1965, Rycroft et al. 1975, Ivanov 1981). Water is therefore believed to move much more slowly through the catotelm (Chason \& Siegel 1986). Data for a Russian bog (Ivanov [1953], cited in Damman 1986) suggests that only about $1 \%$ of total run-off leaves through the catotelm. In contrast, the acrotelm is a thin outer shell, strongly influenced by rapid changes in precipitation, evaporation and transpiration, where water may move rapidly either as surface run-off or as ground water within porous peats. At Handspike Point, the dye tests confirm that gravity drives a general surface water flow over and through the acrotelm peats.

The deep sampling data show that, at Handspike, the surface patterns are preserved in the catorelm and have persisted as the mire has grown upwards. The internal structure of the mire is, therefore, grossly heterogeneous, with multiple, vertically interleaved layers of greater and lesser bulk density (and greater or lesser hydraulic conductivity) aligned at varying angles to the ground water pressure gradient rather like vertical walls or curtains. Ground water flow within the catotelm may therefore be extremely complex. Test pits which probably extended into the upper catotelm suggest that (in the ridges at least) there is significant resistance to ground water flow.

The material sampled at depth comprises roughly 5$6.5 \%(\mathrm{w} / \mathrm{v})$ organic matter, the remainder being water. However, not all of this is free to flow as ground water. Moisture which remains immobile and does not seep out under the influence of a small pressure gradient is said to be bound. This includes water which is physically or molecularly bound to organic colloids or other substances, intracellular water within cell cavities in partially decayed plants, and water effectively sealed in single-ended pores and very small capillaries (Ivanov 1981). The low $\mathrm{pH}$ waters which are characteristic of such mires retard the breakdown of plant tissue (Moore \& Bellamy 1974, Jefferies \& Mills 1990). Deep cores taken from the troughs included brown, gelatinous organic material which may have been colloidal in nature. Data from Ivanov (1981) indicated that the total quantity of immobile water in mires may be as high as $100 \%$ of dry weight for molecularly bound water and up to $300 \%$ of dry weight as water locked within cells. In total, therefore, up to $400 \%$ of the dry weight may be immobile water, with the remainder being held by capillary action but capable of being mobilised through gravity or pressure gradients created by the liquid's own weight. The large elastic storativity of peat (Hemond \& Goldman 1985) allows mire surfaces to rise and fall as water levels vary in response to rainfall events and the diurnal cycle of evaporation and transpiration (Gilman 1994). Once the capacity of the mire to accommodate excess water is exceeded, water must be shed. Contrasts in hydraulic conductivity between acrotelm and catotelm may explain why surplus water flows preferentially on the surface and relatively little is observed flowing out of the mire around its periphery.

Raised mires are, therefore, an interesting phenomenon, where large quantities of water can be held on stable slopes against the force of gravity. They also represent a dynamic balance between the opposing forces of gravity and upward growth (Moore \& Bellamy 1974). As the mire produces more peat, the water table also rises, allowing continued upward growth. At Handspike Point, there is the added complication of a (geologically) rapidly emerging marine platform. Here, there may be a balance, also, between vertical emergence and seaward expansion of the mire. Assuming sea-level stabilisation at 7000 years BP (Adamson et al. 1988) and a width of the marine terrace of 500$700 \mathrm{~m}$, lateral emergence of land from the sea at Handspike Point is about $70-100 \mathrm{~mm} \mathrm{yr}^{-1}$. There appears to be no reason why the mire should not continue to grow seaward as the island rises. The principal limiting factor is probably water to maintain mire expansion.

The deep sampling suggests vertical non-homogeneity in the peat which is mimicked in the ridges and troughs (fig. 8). These features may represent variations in mire development over time, possibly in response to changing environmental conditions. Chason \& Siegel (1986) suggested that vertical bulk-density variations are an indicator of the degree of peat decomposition. Much of the decomposition occurs in the acrotelm and is, therefore, largely influenced by climate. Heinselman (1965) described verrical variations in string bogs from Upper Michigan which are interpreted to be climatically induced. Equally, the observed variations may merely represent the result of taking a thin sample through inherently non-homogeneous material.

Using the sampling techniques described here, it was possible to obtain uncompressed samples only within the upper $1500 \mathrm{~mm}$, representing about one-third of total mire thickness. The data strongly suggest that the patterns are preserved at depth, with a similar orientation to that observed on the surface. Confirmation of these initial impressions will require further subsurface sampling. Deeper sampling would also test whether or not these features remain vertical at depth or show some downslope displacement, implying mire creep. Drury (1956) noted that string bog ridges drag against islands but elsewhere are convex downslope, which he took to suggest some downslope movement. Pearsall (1956) also invoked gravity and downslope movement in the development of mire patterns. Certainly, if the ridge-trough patterns persist to the mire base, it implies that they formed at an early stage, when the mire was very thin, and have been preserved as the mire has grown upwards. Wenner (1947), working on string bogs in Labrador, confirmed that the ridges and troughs retain their separate form to the bottom of the bog. Similar conclusions were reached by Walker \& Walker (1961), in their study of patterned Irish peat bogs. However, Thomson (1983) and Foster et al. (1983), working on North American string bogs, concluded that patterns developed after the initial establishment of relatively uniform peatland. Ratcliffe \& Walker (1958) reached a similar conclusion in their study of patterned raised mires in Scotland. It seems reasonable that, over time and under the influence of varying biotic, climaric, hydrologic and gravitational factors, pattern development may be initiated, maintained or terminated. The interpreted vestigial patterns within Area A may be an example of pattern termination. 


\section{Accretion Rates}

The steep plateau slopes define the limit of former marine erosion when the sea reached its present high level (Adamson et al. 1988). Since then, the island has been subjected to continuous uplift, resulting in a progressive exposure of the raised marine platform (Selkirk et al. 1990b). Mires $5 \mathrm{~m}$ thick occur within $20 \mathrm{~m}$ of the plateau slope base. These mires are presumed to have commenced forming shortly after sea-level stabilisation. Taking this to be 7000 years BP implies mire accretion of about $0.7 \mathrm{~m}$ per thousand years.

The total width of the marine terrace around Handspike Point is about $500-700 \mathrm{~m}$, and the thickest recorded mire is $5.9 \mathrm{~m}$. within Area A. This occurs over a shallow terrace depression located about $250 \mathrm{~m}$ west of the scarp base. Assuming sea-level stabilisation 7000 years BP and a more or less constant rate of terrace emergence, this point would have been shoreline about 3500-4500 years ago. Here, mire accretion rates may be as high as $1.7 \mathrm{~m}$ per thousand years. Assuming an average accretion rate in the central portion of the mire of about $1.0 \mathrm{~m}$ per thousand years, the peat samples collected at $1.5 \mathrm{~m}$ are therefore estimated to be about 1500 years old.

\section{Wind}

It was doubtless the very striking presence of the Pleurophyllum, accentuating the ridges, that caught Hamilton's eye during the 1911 AAE. His misnomer "wind rows" has persisted to the present day. The prevailing winds as measured at the meteorological station (fig. 1), are from $290^{\circ}$ (Streten 1988), whereas the average pattern orientations in Areas $\mathrm{A}$ and $\mathrm{B}$ are $050^{\circ}$ and $070^{\circ}$ respectively. This range in pattern orientation, is roughly parallel to the southwest winds which are associated with an antarctic air flow and are potentially the most destructive to vegetation, frequently carrying snow or ice pellets. Along most of the west coast, such winds are buffered by the plateau. However, at Handspike Point, these winds cross the marine terrace unhindered towards Hasselborough Bay. Feldmark on the plateau includes bryophytes aligned in rows almost parallel to the prevailing wind direction (Selkirketal. 1990a). While wind may not be the principal factor, either in the formation of the patterns or in promoting Pleurophyllum colonisation on the ridges, the present pattern orientation may well be advantageous in terms of minimising damage from the most destructive winds.

\section{Comparisons with Other Forms of Patterned Mire}

The Handspike mires display similarities to a number of other forms of patterned mire, in particular eccentric and concentric domed mires and string bogs. In overall morphology and physical setting, they are most similar to the Zone 6 eccentric domed mires of Moore \& Bellamy (1974). Climate appears to play a significant role in determining mire morphology and forms an integral part of many mire classification schemes, e.g. Moore \& Bellamy (1974), Knollenberg (1964), Dewez et al. (1984), Allington (1961). Moore \& Bellamy (1974) provided climatic diagrams typifying nine principal European mire types. Only eccentric and concentric raised mires and string bogs are characterised by significant ridge-trough patterns. On the basis of climate alone, the Handspike mires do not readily fit any classification. Their physical characteristics, in particular the ridge-trough patterns and domed or raised cross-sections, suggest affinities to the three patterned-mire types noted above. These, however, form under climatic conditions significantly different to those close to sea level on Macquarie Island. These differences are summarised in table 2, the most obvious being seasonally persistent periods of frost. It is the non-patterned blanket mires of the UK and Ireland and the plateau mires of the Baltic region which form, under conditions which more closely approximate those occurring close to sea level on Macquarie Island, characterised by high, persistent rainfall, a restricted temperature range, high precipitation relative to evaporation and no mean monthly temperatures less than $0^{\circ}$. It is, therefore, probably little coincidence that non-patterned blanket mires are common on the wider portions of the raised marine terrace from Handspike Point south to Aurora Point and within the Green Gorge basin on the central east coast. Hence, the patterned mires at Handspike Point appear to be anomalies

TABLE 2

Climatic Comparison between Sea Level on Macquarie Island and Sites of Principal Mire Types in Northern Europe*

Comparison between sea-level climate on Macquarie Island and climatic criteria associated with the principal mire types of northern Europe. The Handspike patterned mires display physical similarities to eccentric raised mires but form under climatic conditions similar to those associated with the non-patterned European plateau and blanket mires, i.e. characterised by higher rainfall and no minimum monthly temperatures below freezing. The Macquarie patterned mires, therefore, appear to be an anomaly, and this may in part explain their very limited distribution on the island.

\begin{tabular}{|c|c|c|c|c|c|c|}
\hline & \multirow[t]{2}{*}{ Macquarie Is } & \multicolumn{2}{|c|}{ Non-patterned European } & \multicolumn{3}{|c|}{ Patterned European Mires } \\
\hline & & Plateau & Blanket & Concentric & Eccentric & Aapamires \\
\hline Mean Temperature (T) & 4.7 & 9.4 & 10.2 & 6.3 & 1.8 & -1.2 \\
\hline Months with Mean $\mathrm{T}<0$ & nil & nil & nil & 5 & 6 & 8 \\
\hline Mean Annual Rainfall & 903 & 838 & 1439 & 583 & 559 & 520 \\
\hline Maximum Monthly Rainfall & 90 & 85 & 110 & 70 & 80 & 75 \\
\hline Minimum Monthly Rainfall & 60 & 50 & 95 & 35 & 30 & 20 \\
\hline
\end{tabular}

* Macquarie Island data from Bureau of Meteorology (1975), National Parks and Wildlife Service (1987) and Streten (1988). European data from Walters \& Lieth (1960) and Moore \& Bellamy (1974). 
which may have formed in response to slightly different environmental conditions. Climate, however, does not appear to have been a major factor. Palynological data (Selkirk et al. 1988) suggest that the climate on Macquarie Island has been stable for the past 6000 years. The most obvious factor may be increased ground water flow, sufficient to sustain the development of a raised mire. The width of the raised marine platform may also play a role. The terrace reaches its maximum widths of about $1100 \mathrm{~m}$ and $700 \mathrm{~m}$ at Eagle Point and Handspike Point respectively (Selkirk et al. 1990b). Elsewhere, the terrace may simply be too narrow, too steep or the ground water supply inadequate to support the development of raised mires, which are typically several square kilometres in area, and whose development is constrained both by area and water supply (Moore \& Bellamy 1974).

\section{SUMMARY AND CONCLUSIONS}

Patterned mires at Handspike Point occur in two areas and display a more or less consistent NE-SW alignment. Patterns are now aligned parallel and at angles to the contours. Bulk density measurements at depth suggest rhat this alignment has prevailed over much of the mire's history. In Area B, parterns are roughly contour-parallel and display characteristics typical of patterned mires described clsewhere. Ridges are preferentially convex down slope and acr locally as dams, impeding surface water flow. In Area A most of the patterned mire is aligned contour-normal. Rather than exhibiting degraded or chaotic patterns (as one would expect if contour-parallel patterns were re-establishing), the present patterns appear to be in dynamic equilibrium with the growing mire. Patterns are best developed where the troughs are interconnected, permitting surface water drainage. Here, patterns exhibit higher trough peat bulk densities and ridges more readily colonised by Pleurophyllum hookeri.

There is an extensive body of literature which suggests that mire patterns will tend towards a contour-parallel alignment. Where doming occurs in raised mires, for example, patterns form and realign themselves to maintain a concentric orientation around the cupola. At Handspike Point, the apparent vitality of the contour normal patterns suggests advantages in this orientarion. Factors and causes are doubtless complex and almost certainly interrelated. The trough orientation permits large quantities of surplus water to be shed rapidly. Ridges are less waterlogged by virtue of being local ground water mounds (rather than dams). Water levels fluctuate less, thereby enhancing conditions for plants growing on both the ridges and troughs. The present orientation of the patterns also minimises damage from the most potentially destructive winds. Mire accretion may simply be occurring more rapidly than the abiliry of the patterns to adjust, but a more holistic approach suggests that the new orientacions provide a number of unexpected benefits, most parricularly enhanced waterlevel stability.

\section{ACKNOWLEDGEMENTS}

Thanks ro J.J. Scott and J. Dudley for assiscance with the fieldwork, I. Raymond for providing meteorological data, Dr P. Selkirk for an early review of the manuscript and the Australian Antarctic Division for permission to publish this paper. I am particularly indebted to Dr D. Adamson for his support, encouragement, suggestions and critical appraisal of several early versions of the manuscript.

\section{REFERENCES}

AdAmSon, D.A., Selkirk, P.M. \& COlhoun, E.A., 1988: Landforms of acolian, tectonic and marine origin in the Baucr Bay-Sandy Bay region of subantarctic Macquarie Island. Pap. Proc. R. Soc. Tasm. 122(1): 65-82.

Allington, K., 1961: The bogs of central Labrador - Ungava; an examination of their physical characteristics. Geug. Ann. 43: 401-417.

Buelter, D. H., 1965: Hydraulic conductivity of peats. Soil Sci. $100(4): 227-231$.

Boelter, D. H., 1969: Physical properries of peats as related to their degree of decomposition. Soil Sci. Soc. Am. Pruc. 33: 606-609.

BRown, R.J.E. \& PEWE, T.L., 1973: Distribution of permafrost in North America and its relationship to the environment: a review, 1963-1973. In PERMAFROST; North American Contribution, Second International Conference, Regional Distribution and Characteristics of Permafrost. National Academy of Science, Washington DC: $71-100$.

BUREAU OF METEOROLOGY, 1975: CLIMATTC AVERAGES. Australian Government Publishing Service. Canberra.

Chason, D. B. \& Siegel., D. I., 1986: Hydraulic conductivity and relared physical properries of pear, Lost River peatland, Northern Minnesota. Soil Sci. 142(2): 91-99.

Colhoun, E.A. \& Goede, A., 1973: Fossil penguin bones, 140 dates and the raised marine terraces of Macquarie Island: some comments. Search 4: 499-501

DAMMAN, A.W.H., 1986: Hydrology, development, and biogeochemistry of ombrogenous peat bogs with special reference to nutrient relocation in a western Newfoundland bog. Can. J. Bot. 64: 384-394.

DAMMAN, A.W.H. \& DOWHAN, J.J., 1981: Vegetation and habitat conditions in Western Head Bogr, a southern Nova Scotian plateau bog. Can. J. Bot. 59: 1343-1359.

DEWEZ, V., LAGAREC, D. \& PHIPPS, M., 1984: The distribution of some periglacial landforms in Northern Quebec (Canada) as related to climate: an information system approach. Res. Note 47, Dep. Geogr., Univ. of Ottawa.

Drury, W.H., 1956: Bog flats and physiographic processes in the upper Kuskokwim River region of Alaska. Contribution of the Gray Herbarium, Harvard University, No. 178 .

Foster, D.R., King, G.A., Glaser, l'.A. \& Wright, H.E. Jr., 1983: Origin of string patterns in boreal peatlands. Nature 306: $256-258$

GHMAN, K., 1994: HYDROLOGY AND WETLAND CONSERVATION. John Wiley \& Sons, Chichester.

Glastr, P.H. \& Janssens, J.A., 1986: Raised bogs in castern North America: transitions in landforms and gross stratigraphy. Can. J. Bot. 64: 395-415.

Glaser, P.H., WheEler, G.A., Gorham, F. \& Wright, H.E. Jr., 1981: The patterned mires of the Red Lake peatland Norrhern Minnesota: vegetation, water chemistry and landforms, J. Ecol. 69: 575-599.

Grittinger, T.,F., 1970: String bog in southern Wisconsin. Ecolugy 51(5): 928-930.

Hamilton, H., I926: Ecological notes and illustrations of the flora of Macquarie Island. Australasian Antarctic Expedition 1911-1914. Sci. Reps, Ser. C, VII(5).

Heinselmax, M.L., 1965: String bogs and other patterned organic terrain near Sency, Upper Michigan. Ecology 46(1-2): $185-188$

Hemond, H.F., \& Goldman, J.C., 1985: On non-Darcian water 
flow in peat. J. Ecol. 73: 579-584.

INGRAM, H.A.P., 1978: Soil layers in mires: function and terminology. J. Soil Sci. 29: 224-227.

IVANOV, K.E., 1981: WATER MOVEMENT IN MIRELANDS. Academic Press, London.

Jefferies, M. \& Mills, D., 1990: FRESHWATER ECOLOGY. Belhaven Press, London.

Jenkin, J.F. \& Ashton, D.H., 1979: Pattern in Pleurophyllum herbfields on Macquarie Island (Subantarctic). Aust. J. Ecol. 4: 47-66.

KirkPATRICK, J.B. \& GiBSON, N., 1984: Dynamics of a Tasmanian bolster heath string fen. Vegetatio 58: 7l-78.

Knollenberg, R., 1964: The distribution of string bogs in Central Canada in relation to climate. Tech. Rep. 14. Dep. Meteorology, Univ. of Wisconsin.

Mawson, D., 1943: Macquarie Island: irs topography and geology. Australasian Antarctic Expedition 1911-1914. Sci. Reps, Ser. A, V.

Moore, P.D. \& Bellamy, D.J., 1974: PEATLANDS. Gresham Press, Old Woking.

National Parks and Wild life Service, 1987: MACQUARIE ISLAND NATURE RESERVE VISITOR'S HANDBOOK.

Penrsall, W.H., 1956: Two blanket bogs in Sutherland. J. Ecol. 44: 493-516.

Ratcliffe, D.A., \& Walker, D., 1958: The Silver Flowe, Galloway, Scotland. J. Ecol. 46: 407-445.

Rycroft, D.W., Williams, D.J.A. \& Ingram, H.A.P., 1975: The transmission of water through peat. J. Ecol. 63: $535-568$.

Selkirk, D.R., Selkirk, P.M., Bergestrom, D.M. \& Adamson, D.A., 1988: Ridge top peats and palaeolake deposits on Macquarie Island. Pap. Proc. R. Soc. Tasm. 122(1): 8390 .

Selkirk, P.M., Seppelt, R.D. \& Selkirk, D.R., 1990a: SUBANTARCTIC MACQUARIE ISLAND: ENVIRONMENT AND BIOLOGY. Cambridge University Press.

SelKIRK, P.M., AdAMSON, D.A. \& WILSON, M.E., 1990b: Raised marine terrace on north-west coast of Macquarie Island. Proc. Linn. Soc. N.S.W. 112(3): 141-152.
SIEGEL, D.1., 1983: Ground water and the evolution of patterned mires, glacial lake Agassiz peatlands, Northern Minnesota. J. Ecol. 71: 913-921.

SIEGLL, D.I, 1988: The recharge-discharge function of werlands near Juneau, Alaska: Part I. Hydrological Investigarion.s. Ground Water 26(4): 427-434.

STRETEN, N.A., 1988: The climate of Macquarie Island and its role in atmospheric monitoring. Pap. Proc. R. Soc. Tasm. 122(1): 91-106

Siors, H., 1961: Surface patterns in boreal peatland. Endeavour 20: $217-224$

TAYIOR, B.W., 1955: The flora, vegetation and soils of Macquarie Island. ANARE Rep., Ser. B(2)

THOM, B.G., 1972: The role of spring thaw in string bog genesis. Arctic 25(3): 236-239

THOMson, E., 1983: Origin of surface patterns in a subarctic peatland. In Fuchsman, C.H. \& Spigarelli, S.A. (Eds): PROCEEDINGS OF THE INTERNATIONAL SYMPOSIUM ON PEAT UTILIZATION: 5-12.

Walker, D. \& Walker, P.M., 1961: Stratigraphic evidence of regeneration in some Irish bogs. J. Ecol. 49: 169-185.

WALTERS, H. \& LIETH, H., 1960: KLIMADIAGRAMMWELTATLAS. Jena.

WASHBURN, A.L., 1979: GEOCRYOLOGY. A SURVEY OF PERIGLACIAL PROCESSES AND ENVIRONMENTSS. Edward Arnold, London.

Wenner, C., 1947: Pollen diagrams from Labrador. Geog. Ann. 29: $137-373$

WHINAM, J., 1985: The characteristics and origin of the string bogs on Mt. Wellington, Tasmania. Unpubl. B.A. (Hons.) thesis, Geog. Dep., Univ.'Tasm.

Whinam, J. \& KirkPATRICK, J.B., 1994: The Mount Wellington string bog, Tasmania. Pap. Proc. R. Soc. Tasm. 128(1): $63-68$.

(accepred 17 October 1995) 
